University of Nebraska - Lincoln

DigitalCommons@University of Nebraska - Lincoln

\title{
Change in atmospheric mineral aerosols in response to climate: Last glacial period, preindustrial, modern, and doubled carbon dioxide climates
}

\author{
Natalie M. Mahowald \\ National Center for Atmospheric Research \\ Daniel R. Muhs \\ U.S. Geological Survey, dmuhs@usgs.gov \\ Samuel Levis \\ National Center for Atmospheric Research \\ Philip J. Rasch \\ National Center for Atmospheric Research \\ Masaru Yoshioka \\ National Center for Atmospheric Research \\ See next page for additional authors \\ Follow this and additional works at: https://digitalcommons.unl.edu/usgsstaffpub \\ Part of the Earth Sciences Commons
}

Mahowald, Natalie M.; Muhs, Daniel R.; Levis, Samuel; Rasch, Philip J.; Yoshioka, Masaru; Zender, Charles S.; and Luo, Chao, "Change in atmospheric mineral aerosols in response to climate: Last glacial period, preindustrial, modern, and doubled carbon dioxide climates" (2006). USGS Staff -- Published Research. 166.

https://digitalcommons.unl.edu/usgsstaffpub/166

This Article is brought to you for free and open access by the US Geological Survey at DigitalCommons@University of Nebraska - Lincoln. It has been accepted for inclusion in USGS Staff -- Published Research by an authorized administrator of DigitalCommons@University of Nebraska - Lincoln. 


\section{Authors}

Natalie M. Mahowald, Daniel R. Muhs, Samuel Levis, Philip J. Rasch, Masaru Yoshioka, Charles S. Zender, and Chao Luo 


\title{
Change in atmospheric mineral aerosols in response to climate: Last glacial period, preindustrial, modern, and doubled carbon dioxide climates
}

\author{
Natalie M. Mahowald, ${ }^{1}$ Daniel R. Muhs, ${ }^{2}$ Samuel Levis, ${ }^{1}$ Philip J. Rasch, ${ }^{1}$ \\ Masaru Yoshioka, ${ }^{1,3}$ Charles S. Zender, ${ }^{4}$ and Chao Luo ${ }^{4}$ \\ Received 7 September 2005; revised 28 December 2005; accepted 17 February 2006; published 31 May 2006.
}

[1] Desert dust simulations generated by the National Center for Atmospheric Research's Community Climate System Model for the current climate are shown to be consistent with present day satellite and deposition data. The response of the dust cycle to last glacial maximum, preindustrial, modern, and doubled-carbon dioxide climates is analyzed. Only natural (non-land use related) dust sources are included in this simulation. Similar to some previous studies, dust production mainly responds to changes in the source areas from vegetation changes, not from winds or soil moisture changes alone. This model simulates a $+92 \%,+33 \%$, and $-60 \%$ change in dust loading for the last glacial maximum,

preindustrial, and doubled-carbon dioxide climate, respectively, when impacts of carbon dioxide fertilization on vegetation are included in the model. Terrestrial sediment records from the last glacial maximum compiled here indicate a large underestimate of deposition in continental regions, probably due to the lack of simulation of glaciogenic dust sources. In order to include the glaciogenic dust sources as a first approximation, we designate the location of these sources, and infer the size of the sources using an inversion method that best matches the available data. The inclusion of these inferred glaciogenic dust sources increases our dust flux in the last glacial maximum from 2.1 to 3.3 times current deposition.

Citation: Mahowald, N. M., D. R. Muhs, S. Levis, P. J. Rasch, M. Yoshioka, C. S. Zender, and C. Luo (2006), Change in atmospheric mineral aerosols in response to climate: Last glacial period, preindustrial, modern, and doubled carbon dioxide climates, J. Geophys. Res., 111, D10202, doi:10.1029/2005JD006653.

\section{Introduction}

[2] Mineral aerosols (dust) interact with climate and biogeochemistry in several important ways. Mineral aerosols affect climate by both absorbing and scattering incoming solar radiation and outgoing planetary radiation, thereby modifying the radiative balance of the atmosphere [e.g., Miller and Tegen, 1998; Penner et al., 2001; Tegen, 2003]. Additionally, mineral aerosols may act as cloud condensation nuclei or ice nuclei, thereby modifying cloud properties, which impact climate [e.g., Rosenfeld et al., 2001; DeMott et al., 2003; Mahowald and Kiehl, 2003]. Mineral aerosols can also impact atmospheric chemistry via hetereogeneous reactions and changes in photolysis rates [e.g., Dentener et al., 1996]. Finally mineral aerosols contain iron and other nutrients, which may modify ocean biogeochemistry, and thus ocean uptake of carbon dioxide [e.g., Martin,

\footnotetext{
${ }^{1}$ National Center for Atmospheric Research, Boulder, Colorado, USA. ${ }^{2}$ U.S. Geological Survey, Denver, Colorado, USA.

${ }^{3}$ Institute for Computational Earth Systems Science, University of California, Santa Barbara, California, USA.

${ }^{4}$ Department of Earth System Science, University of California, Irvine, California, USA.
}

Copyright 2006 by the American Geophysical Union. 0148-0227/06/2005JD006653\$09.00
1990], or act to fertilize tropical forests over long time periods [e.g., Chadwick et al., 1999; Swap et al., 1992; Okin et al., 2004]. Mineral aerosols have even been implicated as the cause of some of the $80 \mathrm{ppm}$ change in carbon dioxide between glacial and interglacial time periods through their biogeochemical interactions [e.g., Martin, 1990; Broecker and Henderson, 1998; Watson et al., 2000].

[3] Geologic records and historical records suggest that mineral aerosols are sensitive to climate change. Ice core records suggest that high latitude dust deposition rates were 2-20 times larger during glacial periods than interglacial periods such as the present [e.g., Fisher, 1979; Petit et al., 1990; Steffensen, 1997]. Marine sediment records suggest 3-4 times higher dust deposition globally during glacial times compared to interglacial periods [Rea, 1994]. Within the last 40 years, observations of dust concentrations, generated in Africa, have varied by a factor of 4 at Barbados, due to natural climate variability and/or human induced climate change [Prospero and Nees, 1986; Mahowald et al., 2002; Prospero and Lamb, 2003].

[4] Modeling studies of mineral aerosols have been conducted over the past 15 years [e.g., Joussaume, 1990], but only recently have models included the radiative feedbacks of dust onto climate [e.g., Miller and Tegen, 1998; Woodward, 2001]. In this study we show results from the 
inclusion of the dust cycle into a new climate system model, the National Center for Atmospheric Research's (NCAR) Community Climate System Model (CCSM3). Additionally, we look at the impact of climate change on the dust cycle, similar to Andersen et al. [1998], Joussaume [1993], Mahowald et al. [1999], Mahowald and Luo [2003], Reader et al. [1999], Tegen et al. [2004], and Werner et al. [2002]. However, this study is a first attempt at predicting preindustrial and future dust source, transport and deposition is predicted within a general circulation model, unlike Mahowald and Luo [2003] or Tegen et al. [2004] which used an offline chemical transport model. Future studies will look at the feedback of dust onto climate and include a dynamic vegetation model.

[5] An additional contribution of this paper is the presentation of terrestrial sediment data that act as additional constraints on estimates of dust deposition fluxes during the last glacial period. Geologic studies on many continents have shown that there were much larger dust fluxes on land during the last glacial period, especially during the last glacial maximum (LGM) [e.g., Kohfeld and Harrison, 2001]. This increased dust flux is recorded in many settings, but most dramatically in loess deposits. Loess is defined as windblown terrestrial sediments that can be identified distinctly in the field by physical properties, such as siltsized particles [Pye, 1987; Muhs and Bettis, 2003]. Loess occupies large areas in North America (particularly the United States), South America (particularly Argentina), Asia (particularly China and Siberia), and Europe (particularly Hungary, Poland, Ukraine, and Russia). Smaller areas of loess are also found in Tajikistan, Uzbekistan, Western Europe, Canada, New Zealand, and around the margins of some deserts (e.g., loess on the fringes of the Takla Makan Desert in China and "perisaharan" loess around the Sahara Desert in Africa).

[6] Generally, loess deposits can be formed from two different processes: from glacial or "desert" dust sources. In the classical glacial model of loess deposition, silt-sized particles are produced first by grinding of rocks by large ice sheets. These "glaciogenic" silt-sized particles are then carried from the ice sheets by meltwaters to large river systems such as the Mississippi and Missouri (in North America) or the Rhine and Danube (in Europe). Seasonal deposition of channel-bar silts or overbank silts in river valleys then allows entrainment by wind. Much of the atmospheric dust modeling has focused on dust from desert dust regions, because much of the atmospheric dust is associated with desert regions during the current climate [e.g., Prospero et al., 2002]. In desert regions, the soil particles appropriate for atmospheric entrainment are associated with topographic lows, where easily erodible particles have accumulated after being eroded by water or wind from adjacent highlands [e.g., Prospero et al., 2002]. In either arid or glacial regions, the saltation process modifies the size distribution, producing or entraining small particles which can be easily entrained into the atmosphere [e.g., Gillette, 1979; Mahowald et al., 2006]. During the last glacial period, it is likely that the glaciogenic sources of atmospheric dust were active, and for the first time, we include these sources into an atmospheric modeling study.

[7] In section 2 we describe the mineral aerosol model used for this study. In section 3, we describe the terrestrial sediment records used to create a deposition map for the last glacial maximum (with more details in the online auxiliary material $^{1}$ ). In section 4 , we compare the results of the model to current climate observations. In section 5 we examine the response of mineral aerosols to climate. In section 6 we use loess records to estimate glaciogenic sources of mineral aerosols. In section 7 we summarize the results of this study.

\section{Modeling Methodology}

\subsection{Mineral Aerosol Modeling}

[8] The National Center for Atmospheric Research's (NCAR) Community Climate System Model (CCSM3) is a coupled atmosphere, land, ocean and sea-ice model [Collins et al., 2006]. This model is used for climate change scenarios, such as for the Intergovernmental Panel on Climate Change [Houghton et al., 2001]. Here we describe mineral aerosol source and deposition algorithms added to the Community Land Model (CLM3) [Dickinson et al., 2006] and Community Atmosphere Model (CAM3) [Collins et al., 2004] to parameterize the source, transport and deposition of dust.

[9] The dust source mechanism follows the Dust Entrainment and Deposition Module [Zender et al., 2003a] and work conducted in the offline Model of Atmospheric Transport and Chemistry (MATCH) [Mahowald et al., 2002; Luo et al., 2003; Mahowald et al., 2003; Mahowald and Luo, 2003]. The sources of dust are assumed to be dry, unvegetated regions with strong winds based on our present understanding of dust generation [e.g., Mahowald et al., 2005]. The magnitude of the source of the dust is calculated within the CLM3, and thus, soil moisture and wind friction are the same as in the calculation of heat and moisture fluxes in the model. In the default version of the model, the satellite-based vegetation climatology used for the land surface calculations in the model is used to calculate dust source areas [Bonan et al., 2002] (other sensitivity studies are described below). When the total leaf area index plus the stem area index is below 0.1 , the area of the gridbox available for dust generation increases linearly with decreasing vegetation cover.

[10] We summarize here the source scheme parameterizing dust entrainment into the atmosphere, although it is described in more detail in Zender et al. [2003a]. The model calculates a wind friction threshold velocity, above which dust is entrained into the atmosphere. The model assumes that the optimum size distribution of soil particles for saltation and subsequent vertical flux $(\sim 75 \mu \mathrm{m})$ is available. However, after the dust flux is calculated, a soil erodibility factor is multiplied by the dust source magnitude to include the impact of differences in soil size and texture following the "preferential source" concept [Ginoux et al., 2001]. We use the geomorphic soil erodibility factor described by Zender et al. [2003b]. A wind friction threshold is calculated following Iversen and White [1982]. This threshold is modified for two different processes in the model. Following Fecan et al. [1999], the threshold wind friction velocity increases with increasing soil moisture. The fetch of the winds over this erodible surface is allowed to modify the

\footnotetext{
${ }^{1}$ Auxiliary material is available at $\mathrm{ftp}: / / \mathrm{ftp}$.agu.org/apend/jd/ 2005 jd006653.
} 
wind friction velocity threshold as well [Gillette et al., 1998]. Once the wind friction threshold velocity is calculated, the horizontal saltation fluxes are calculated [White, 1979]; vertical fluxes are a small fraction of the horizontal flux and depend on the size of the aerosol [Marticorena and Bergametti, 1995; Zender et al., 2003b].

[11] The transported aerosols are assumed to have a subbin distribution based on a log-normal distribution with a mass median diameter of $3.5 \mu \mathrm{m}$ within each bin, larger than in our previous studies following the results of Grini and Zender [2004] and Hand et al. [2004]. We use four bins with the following source apportionment: $0.1-1.0 \mu \mathrm{m}$ $3.8 \% ; 1.0-2.5 \mu \mathrm{m} 11 \% ; 2.5-5.0 \mu \mathrm{m} 17 \%$ and $5.0-$ $10.0 \mu \mathrm{m} 67 \%$ (all values in diameter) in order to better match the data, as described in Grini and Zender [2004]. This distribution of particles into the size bins has more large particles than previous studies [e.g., Zender et al., 2003a; Mahowald et al., 2002].

[12] Deposition processes include dry gravitational settling, turbulent dry deposition and wet deposition during precipitation events. Both dry depositional processes are modeled using parameterizations described in Zender et al. [2003a], with a mass flux advection scheme in order to parameterize vertical fall rates correctly [Rasch et al., 2001; Ginoux, 2003]. Wet depositional processes are parameterized within the CAM3 similar to Rasch et al. [2001].

[13] Note that in this study, the dust does not feedback through radiative impacts onto the climate in the model runs. Simulations are conducted for at least 10 years for most simulations although only 4 years of simulations are conducted for the glaciogenic sources.

\subsection{Climate Scenarios Simulated}

[14] Four simulations of the current climate are conducted as part of the study, to test the sensitivity of the mineral aerosols to sea surface temperature boundary conditions and resolution. The base case is simulated at T42, which corresponds to a horizontal resolution of $\sim 2.8^{\circ} \times 2.8^{\circ}$ and uses a slab ocean model (SOMTIMIND), while the second case is also simulated at T42 and uses historical sea surface temperatures (AMIP) for 1950-1993. The third study uses fixed SSTs and T85 resolution (T85), which corresponds to approximately $1.2^{\circ}$ by $1.2^{\circ}$ horizontal resolution. Additionally, a base case for the climate change scenarios using the BIOME3 model is used [Haxeltine and Prentice, 1996], where the vegetation from the BIOME3 model is used to determine dust sources following the methodology of Mahowald et al. [1999] (SOM-BASE). These simulations use the monthly mean anomalies between the current climate and the different climates, and add them to the observational monthly mean. These simulations are conducted for at least 10 years and averaged for the results shown here. Due to an error in the coding of the dust source area using the BIOME3 results, which was not discovered until final figures were prepared, the dust source at $0^{\circ}$ longitude is zero. This is not likely to substantially impact the results of this study.

[15] For the climate change studies, several sets of simulations are conducted. First a set of simulations with no change in source area or vegetation is used (TIMIND). These use the base vegetation from the CLM, which is satellite-image-based vegetation for 1992-1993 [Bonan et al., 2002]. The second set of simulations uses the BIOME3 model [Haxeltine and Prentice, 1996] and changes in temperature, precipitation and cloudiness to calculate changes in vegetation between the current climate and the three other climates simulated (BASE). The final set of simulations is similar to the BASE case, but allows carbon dioxide to impact vegetation directly using the BIOME3 model (BASE-CO2). This allows the inclusion of the impact of carbon dioxide fertilization onto vegetation.

[16] The physical climate used for these simulations is based on simulations conducted in previous studies [Kiehl et al., 2006; Otto-Bliesner et al., 2006; Mahowald et al., 2005]. For the last glacial maximum, preindustrial, and current climates, the slab ocean model simulations are derived from ocean/atmosphere/land coupled simulations, and thus include changes in ocean circulation [Otto-Bliesner et al., 2006]. The doubled carbon dioxide experiment was run to equilibrium for climate sensitivity experiments [Kiehl et al., 2006].

[17] Additional source areas are simulated for the last glacial maximum (LGM) simulations. These source areas are considered unvegetated because of glaciogenic processes, not because of equilibrium vegetation changes simulated by the BIOME3 model, and are called glaciogenic sources. A description of the location and reasons for these sources is given in section 5. The dust from these sources is treated identically as those from the other unvegetated sources derived from the BIOME3 model.

\section{Terrestrial Sediment Records}

[18] In this study, we compute eolian mass accumulation rates (MARs), or flux, in units of mass per unit area per year. Loess ages are determined by radiocarbon dating of materials within the loess or in paleosols bracketing it or by direct age determinations on the loess itself by thermoluminescence (TL), infrared-stimulated luminescence (IRSL) or optically stimulated luminescence (OSL) dating. Where loess is not directly dated, it can be estimated to be of lastglacial age in some cases by stratigraphic position and correlation to the deep-sea oxygen isotope record. For this paper, we include terrestrial sediment records for the time period covering $25 \mathrm{ka}$ to $12 \mathrm{ka}$ before present. For the model, we are utilizing a single slice that should be representative of a few thousand years close to the last glacial maximum. Therefore there is an inherent mismatch in the time periods between models and observations that should be kept in mind. Loess mass accumulation rate (MAR) in units of $\mathrm{g} / \mathrm{m}^{2} / \mathrm{yr}$ can be computed as:

$$
\operatorname{MAR}=\left(D_{1} / t\right) \times(B D)
$$

where $D_{1}$ is the depth interval of the loess section (m) over the time period of interest, $t$ is the time period of interest (yr), and BD is the dry bulk density of the sediment $\left(\mathrm{g} / \mathrm{m}^{3}\right)$. We have modified this simple formula to include only those particles that are $<10 \mu \mathrm{m}$ in diameter, which is the particle size range that would have significant radiative transfer effects in the atmosphere [Tegen, 2003], and the particle sizes used in the model described in section 2 . Thus, the 
fine-grained $(<10 \mu \mathrm{m})$ component of the mass accumulation rate $\left(\mathrm{MAR}_{f}\right)$ is computed as:

$$
\operatorname{MAR}_{f}=\left(\mathrm{D}_{1} / \mathrm{t}\right) \times(\mathrm{BD}) \times(f)
$$

where $f$ is the fraction of bulk sediment composed of $<10 \mu \mathrm{m}$ particles. In practice, few investigators measure either bulk density or the $<10 \mu \mathrm{m}$ fraction of loess. For bulk density, we have chosen a value of $1.45 \times 10^{6} \mathrm{~g} / \mathrm{m}^{3}$, which is identical to the value used by Bettis et al. [2003] for midcontinental North American loess and Muhs et al. [2003a] for Alaskan loess. This value is typical of unaltered, dry loess dominated by silt-sized particles, as measured by the core method in laboratories of the U.S. Geological Survey. The exceptions to this are for loess of China, where Kohfeld and Harrison [2003] chose a bulk density value of $1.48 \times 10^{6} \mathrm{~g} / \mathrm{m}^{3}$ and southern Siberia, where Chlachula [2003] used a value of $1.50 \times 10^{6} \mathrm{~g} / \mathrm{m}^{3}$. These slightly higher values are probably reasonable, given that loess in China and Siberia may be somewhat finer-grained than elsewhere. The uncertainties in our MARs due to these differences in bulk densities are probably smaller than due to other uncertainties (described below).

[19] Many loess studies report no particle size data and those that do rarely give information on the abundance of particles that have diameters of $<10 \mu \mathrm{m}$. It is difficult to estimate the fraction of loess that has particles with diameters of $<10 \mu \mathrm{m}$ when this parameter is not measured directly. Nevertheless, many laboratories report various size fractions that allow interpolation for estimating this size fraction. The method of estimating the $<10 \mu \mathrm{m}$ fraction varies from region to region, which we describe below.

\subsection{Sources of Regional Loess Information}

[20] Many of our sources of loess information come from the DIRTMAP ("Dust Indicators and Records of Terrestrial and Marine Paleoenvironments") databases, which are described by Kohfeld and Harrison [2001] and Derbyshire [2003]. This project was begun specifically to provide databases of eolian particle accumulation rates for the late Quaternary, and more specifically for the last glacial period and the Holocene. Many of the compilations used herein are derived directly or indirectly from DIRTMAP papers published in the September 2003 issue of Quaternary Science Reviews dedicated to this project.

[21] Some of the most extensive and best-studied loess deposits in the world are in China. Loess in China has long been considered to be derived from deserts to the north or northwest of the Chinese Loess Plateau [Liu, 1985]. However, there has been considerable disagreement over whether silt particles in Chinese loess are glaciogenic or produced in the deserts that are the immediate source of the loess [Smalley and Krinsley, 1978; Smalley, 1995; Sun, 2002a, 2002b; Wright, 2001a, 2001b]. For the present compilation, we used the MARs calculated for the last glacial period by Kohfeld and Harrison [2003], which in turn are derived from data compiled by Sun et al. [2000]. No modifications were made to their bulk MAR calculations. For modifications of the bulk loess MARs to include only the $<10 \mu \mathrm{m}$ fraction, we used particle size data collected across the Chinese Loess Plateau by Nugteren and Vandenberghe [2004]. These investigators provided the abundance of
$<16 \mu \mathrm{m}$ particles at various localities in the region. We assumed that $62.5 \%$ of the $<16 \mu \mathrm{m}$ fraction (assuming an even distribution with size) is a reasonable approximation of the $<10 \mu \mathrm{m}$ fraction and modified the bulk MAR calculations for China using the closest localities of Nugteren and Vandenberghe [2004] to our localities.

[22] Loess deposits are also extensive in North America, particularly the central part of the continent, and Washington, Idaho and Alaska. Loess in Washington is not included in our study because it is most likely of late-glacial and Holocene age [Busacca et al., 1992]. In central North America, east of the Missouri River, loess has clear linkages to the Laurentide ice sheet and is dominantly glaciogenic [Bettis et al., 2003]. West of the Missouri River, on the Great Plains, most loess is probably nonglaciogenic, although there may be a component of glaciogenic silt derived from Rocky Mountain glaciers [Aleinikoff et al., 1998, 1999]. The origin of loess in Idaho is unknown, although there are probable links to glacial history in the northern Rocky Mountains [Pierce et al., 1982]. For most localities, we used data compiled by Muhs et al. [2003a] for Alaska and Bettis et al. [2003] for central North America. For Alaska, we included all localities that dated to the last glacial period, with no modifications, but added an additional lacustrine record reported by Muhs et al. [2003b]. For central North America, we used all data compiled by Bettis et al. [2003], but included only those calculations that covered the entire last glacial period, from $\sim 25 \mathrm{ka}$ to $\sim 12 \mathrm{ka}$. In addition, we used MARs for a new loess section reported by Roberts et al. [2003], and additional loess sections at Fort Morgan, Colorado; McCook, Nebraska; and Morrison, Illinois (D. R. Muhs, unpublished data) and localities in Indiana and Ohio reported by Ruhe and Olson [1978] and Rutledge et al. [1975]. For Idaho, we used localities in Pierce et al. [1982], with the assumption that the upper part of their "Loess Unit A" dates to $\sim 25-12 \mathrm{ka}$. In North America, loess sedimentology has traditionally been characterized by particle size classes, namely, $<2 \mu \mathrm{m}$, $2-20 \mu \mathrm{m}, 20-50 \mu \mathrm{m}$, and $>50 \mu \mathrm{m}$. We approximated the $<10 \mu \mathrm{m}$ fraction by adding half of the abundance of $2-20 \mu \mathrm{m}$ particle size fraction to the $<2 \mu \mathrm{m}$ fraction, which assumes that the particles are evenly distributed across size distriubtions. Most analyses were conducted by E.A. Bettis III in his laboratories at the University of Iowa; many of these data are found in Muhs and Bettis [2000] and Muhs et al. [2003a].

[23] Europe has extensive loess deposits in the region immediately south of the farthest extent of the Scandinavian ice sheet. Detailed studies of loess provenance have not been conducted in Europe. Nevertheless, it is likely that much of the sediment is derived from outwash deposits of major river valleys that drained the Scandinavian ice sheet [Smalley and Leach, 1978]. Thus, loess is thick adjacent to the Rhine and Danube Rivers. Other loess deposits were probably derived from rivers draining ice caps and valley glaciers that covered mountain ranges such as the Alps and Carpathians. Frechen et al. [2003] presented MARs for a number of localities in Europe, most of them sites that had been studied by M. Frechen himself and his co-workers. We used some of these data, but recalculated MARs because Frechen et al. [2003] used a bulk density value that we think is too high for loess. Instead, we used a bulk density 
value of $1.45 \times 10^{6} \mathrm{~g} / \mathrm{m}^{3}$, which we think is a more realistic value for European loess. Many of the localities studied by Frechen et al. [2003] show reversals of TL or IRSL ages and we are uncertain as to how to estimate MARs in these situations. In addition, Frechen et al. [2003] made separate calculations for the early and later parts of the last-glacial period. For comparability with other continents, we calculated MARs for localities in Europe where we could find sufficient stratigraphic data to make an estimate for the entire last-glacial period. There are surprisingly few particle size data for European loess. We estimated that $\sim 25 \%$ of the bulk loess consists of particles $<10 \mu \mathrm{m}$, based on data in Antoine et al. [1999] from northwestern France and Vandenberghe and Nugteren [2001] from Belgium. Full references for the loess data we used for Europe are given in the supplementary data table.

[24] Loess is widespread in western Russia and is continuous over large tracts of the east European Plain [Velichko et al., 1984]. In this region, loess is found over the area to the southeast of the limits of the Scandinavian ice sheet, from about latitude $48^{\circ} \mathrm{N}$ to $64^{\circ} \mathrm{N}$ [Velichko, 1991]. As in western Europe, detailed provenance studies of Russian loess have not been conducted, but it is likely that most of the loess is glaciogenic, derived from outwash carried in the valleys of the Bug, Dnepr, Don, and Volga Rivers, which drained the Scandinavian ice sheet. Loess of last-glacial age rests on the interstadial Bryansk paleosol, which has radiocarbon ages of $\sim 28 \mathrm{ka}$ (calendar years B.P.) [Velichko et al., 1984]. OSL ages confirm that the loess overlying this paleosol dates to the last glacial period [Little et al., 2002]. We computed MARs for loess in this region using stratigraphic data from Velichko et al. [1984], Virina et al. [2000], Little et al. [2002], and Rutter et al. [2003]. Abundances of the $<10 \mu \mathrm{m}$ fraction were estimated from particle size data in Velichko et al. [1984].

[25] Loess is also extensive over southern Siberia and the Yakutia region of central and northern Siberia. For southern Siberia, Chlachula [2003] presented detailed data on MARs for the DIRTMAP project. Unfortunately, his calculations are in error by several orders of magnitude. We recalculated MARs for this region using Chlachula's [2003] data for loess thickness, age and bulk density. South of southern Siberia, loess mantles parts of Tadjikistan. We calculated a MAR for one of the better-studied loess sections in this region, using data in Frechen and Dodonov [1998]. In the Yakutia region of central and northern Siberia, much of the landscape is mantled with a silt-and-ice-rich sediment, variously referred to as the "ice complex," "loessial-glacial complex," "loesslike silt," or "yedoma." The origin of this material has been controversial, with various authors suggesting alluvial, lacustrine, marine, weathering, and eolian origins (see review in Péwé and Journaux [1983]). Although some workers have not made conclusive statements about the origin of this ground-ice-rich silt [Sher et al., 2005], others have concluded that it is probably loess [Péwé and Journaux, 1983; Kaplina and Lozhkin, 1984]. Based on the lines of reasoning presented by Péwé and Journaux [1983], it seems likely to us that most of the ice-rich silt in central Yakutia is loess and by extension, much of that in northern Yakutia [Kaplina and Lozhkin, 1984] is probably loess also. We used the loess thicknesses and ages presented by Kaplina and Lozhkin [1984] and Sher et al. [2005], and particle size data presented by Péwé and Journaux [1983] to calculate MARs for this region. Corrections for the different mass and volume of the amount of ground ice present were made using data from Sher et al. [2005].

[26] Although loess is extensive in South America, particularly Argentina and neighboring parts of Uruguay and Paraguay, little is known of its age. Furthermore, studies of its origins have only been undertaken in the past decade or so and results indicate its genesis is complex [Zárate and Blasi, 1993; Gallet et al., 1998; Smith et al., 2003]. We have made some very tentative estimates of MARs for last-glacial loess in Argentina, using data from Kröhling [1999], Kröhling and Iriondo [1999], and Kemp et al. [2004]. Abundances of the $<10 \mu \mathrm{m}$ fraction were estimated from data in Bidart [1993].

\subsection{Uncertainties With MAR Estimates}

\subsubsection{Completeness of the Loess Record}

[27] It is common for loess deposits to be removed by erosion from their original points of deposition as direct, airfall sediment. In the compilations used in this study, we included only those localities for which we found data that indicate little or no erosion following deposition by wind. Stratigraphic data are the most important criteria that allow an evaluation of the completeness of the loess record. On many continents, the late Quaternary loess record consists of a paleosol or paleosol complex that dates to the last interglacial complex $(\sim 130-80 \mathrm{ka})$, early-last-glacial loess deposit $(\sim 80-60 \mathrm{ka})$, an interstadial paleosol complex ( $\sim 60-30 \mathrm{ka})$, late-last-glacial loess $(\sim 30-10 \mathrm{ka})$, and a modern soil developed in late-last-glacial loess over the past $\sim 10 \mathrm{ka}$. The upper parts of interstadial soils typically date from $\sim 30-25 \mathrm{ka}$. If a loess section has no evidence of an interstadial soil ("Farmdale" paleosol in North America; "Bryansk" paleosol in Russia; "Dubno" paleosol in Ukraine; "L1SS" paleosol in China, etc.), this is evidence that the section has probably been eroded, and the oldest part of last-glacial-age loess is missing. Similarly, if there is no well-developed modern surface soil, this is evidence that the youngest part of last-glacial loess is missing. All sections we included in our compilation have well-developed interstadial soils underlying last-glacial-age loess and well-developed modern soils developed in their upper parts.

[28] It is also possible for loess removed from one position on a landscape to be transported to another position, resulting in an "overthickened" loess record. Most loess removal probably takes place by running water as overland flow (sheetwash or channeled flow) or mass movement (solifluction, creep, or slumping), although eolian re-entrainment can also occur. As a result, topographically lower parts of a landscape often have thicker deposits of loess than valley sides or interfluves. Apparent MARs derived from such localities would overestimate the amount of direct air-fall loess. We avoided, as much as possible, valley-bottom localities or other landscape positions where there is evidence for some significant portion of the loess record being derived from processes other than direct air fall.

\subsubsection{Dating Methods}

[29] In midcontinental North America, Alaska, Europe and Russia, basal ages of loess are derived mostly from radiocarbon ages of the paleosol underlying last-glacial age 
Table 1. Current Climate Desert Dust Budgets

\begin{tabular}{lcccc}
\hline \multicolumn{1}{c}{ Case } & Source, Tg/year & Loading, Tg & Lifetime & Optical Depth \\
\hline SOM-TIMIND (slab ocean model) & 4380 & 27.4 & 2.3 & 0.037 \\
AMIP (historical SSTs) & 4230 & 28.4 & 2.3 & 0.035 \\
T85 (higher horiz. resolution) & 3870 & 22.2 & 2.1 & 0.029 \\
SOM-BASE (BIOME3 vegetation) & 4670 & 31.1 & 2.7 & 0.045 \\
\hline
\end{tabular}

loess. These paleosols date from a major interstadial period in the late Quaternary, as described above. Because the ages are usually from organic matter in soils that formed before deposition of last-glacial-age loess, they are maximumlimiting ages for the overlying loess. Loess deposition could have begun much later than the time of paleosol formation. Thus, our MARs are conservative and may well underestimate the actual flux if we consider the entire last glacial maximum. Of course, the model considers only one time slice of this period, and thus if the MARs include significant variability driven by processes we are not including in our model, we cannot expect the model to match the deposition rates. Indeed a recent study by Roberts et al. [2003] shows that MARs varied considerably within the last glacial period. Resolution of this variability, however, requires more OSL ages than are usually available.

[30] For the end of loess deposition, most sections are undated. Based on degree of soil development, radiocarbon and ${ }^{10} \mathrm{Be}$ abundances in modern, loess-derived soils and other data, most investigators estimate that last-glacial loess deposition probably ended $\sim 12 \mathrm{ka}$ (in calendar years B.P.) on most continents (e.g., Velichko et al. [1984] for Russia and Bettis et al. [2003] for North America). In the absence of independent age data, we used $12 \mathrm{ka}$ as the age of the termination of loess deposition. In the Great Plains region of North America, China, and parts of Argentina, loess of lastglacial age is overlain by Holocene loess. In these regions, last-glacial and Holocene loesses are separated by a buried soil ("Brady" paleosol in North America; "S0" paleosol in China; "Hypsithermal" paleosol in Argentina). These paleosols mark periods of landscape stability and little or no loess deposition. Radiocarbon ages of organic matter from these paleosols give approximate ages for the termination of last-glacial loess deposition. These estimates are, however, minimum-limiting ages for the termination of last-glacial loess deposition. Thus, again our MARs computed from these data are conservative. In addition to these strictly geologic uncertainties, there are also potential geochemical and isotopic problems with regard to radiocarbon dating of soil organic matter. McGeehin et al. [2001] have reviewed many of the problems with radiocarbon dating of various fractions of soil organic matter.

[31] Loess is potentially one of the most suitable geologic materials for the luminescence family of dating methods. Many of the loess sections compiled here have age control in the form of TL, IRSL or OSL dating. Of these, most investigators now feel that OSL probably yields the most reliable ages [Aitken, 1998]. Nevertheless, many sections have not yet been dated using this method and thus we have had to rely on sections dated by TL and IRSL. Unfortunately, many loess sections with TL and IRSL ages show a considerable number of age reversals (i.e., older apparent ${ }^{14} \mathrm{C}$ or OSL ages that are stratigraphically above younger apparent ${ }^{14} \mathrm{C}$ or OSL ages) within the portion of the section thought to date to the last glacial period (see examples in Frechen et al. [2003]). In those sections where there is no evidence for age reversals, we have used TL, IRSL, and OSL ages as published. However, in those sections where there is abundant evidence of age reversals, we have retained the locality for use if stratigraphic data indicate that the section is uneroded. Our criteria for an uneroded loess section include the presence of an interstadial paleosol, some TL, IRSL or OSL evidence that the loess overlying this paleosol dates to the last glacial period, and the presence of a well-developed (i.e., uneroded) modern soil in the upper part of the loess. For loess sections meeting these criteria, we have assumed a lower boundary age of $\sim 25 \mathrm{ka}$ and an upper boundary age of $\sim 12 \mathrm{ka}$. The deposition fluxes resulting from these estimates are shown in the online auxiliary material, along with more detailed reference lists.

\section{Current Climate Simulations}

[32] Model results for the current climate are summarized in this section. In order to constrain for the globally averaged total emissions (amount of dust entrained into the atmosphere), we adjusted a global constant emission factor in the AMIP scenario to match the available data. One important constraint that we used was to force the globally averaged optical depth of desert dust to be 0.033 at $550 \mathrm{~nm}$, which is the aerosol optical depth found in 1983-2000 assimilations using the methodology developed in Rasch et al. [2001]. Aerosol optical depth is a measure of the amount of radiation absorbed or scattered by the aerosol, and is a function of the vertical column amount of aerosol in the atmosphere, as well as the optical properties of the dust and the size distribution. The value used here is slightly higher than the value of 0.026 deduced by Reddy et al. [2005] for dust or Cakmur et al. [2006], but within the uncertainty range for observations. Note that the satellite optical depth measurement on which this value is based (AVHRR) tends to be lower than other satellite aerosol optical depths. In this model, we use a greater proportion of large particles than in previous studies. Because larger particles have a shorter lifetime and smaller visible extinction coefficient (amount of sunlight absorbed or scattered per gram of atmospheric aerosol), we obtain a larger dust emission than in many previous studies [e.g., Zender et al., 2004; Mahowald et al., 2005] (Table 1).

[33] The lifetime of dust aerosols in this study is shorter than in previous studies (e.g., 5.1 from Luo et al. [2003]; 5.6 in Miller et al. [2006]). This is due mostly to the much larger portion of the largest size bin $(68 \%)$, which has a short lifetime, than previous studies ( $30 \%$ in both). It is also partly due to the shorter wet deposition lifetime ( $~ 8$ days here compared with 10-11 days in Luo et al. [2003] and 12-15 days in Miller et al. [2006]). Detailed bin-segregated 
Table 2. Budgets for Dust Size Bins (SOM Case)

\begin{tabular}{|c|c|c|c|c|c|c|c|}
\hline $\begin{array}{c}\text { Diameter, } \\
\mu \mathrm{m}\end{array}$ & $\begin{array}{c}\text { Dust } \\
\text { Source, } \\
\text { Tg/year }\end{array}$ & $\begin{array}{c}\text { Wet } \\
\text { Deposition, } \\
\text { Tg/year }\end{array}$ & $\begin{array}{c}\text { Dry } \\
\text { Deposition, } \\
\text { Tg/year }\end{array}$ & $\begin{array}{c}\text { Wet } \\
\text { Deposition } \\
\text { Lifetime, } \\
\text { days }\end{array}$ & $\begin{array}{c}\text { Dry } \\
\text { Deposition } \\
\text { Lifetime, } \\
\text { days }\end{array}$ & $\begin{array}{c}\text { Column } \\
\text { Burden, Tg }\end{array}$ & $\begin{array}{c}\text { Total } \\
\text { Lifetime, } \\
\text { days } \\
\end{array}$ \\
\hline $0.1-1$ & 172 & 5 & 169 & 7.8 & 278.4 & 3.6 & 7.6 \\
\hline $1-2.5$ & 499 & 46 & 455 & 7.8 & 76.0 & 9.7 & 7.1 \\
\hline $2.5-5$ & 771 & 417 & 356 & 8.1 & 6.9 & 7.9 & 3.7 \\
\hline $5-10$ & 3040 & 2522 & 524 & 8.0 & 1.7 & 11.5 & 1.4 \\
\hline All bins & 4483 & 2990 & 1503 & 8.0 & 4.0 & 32.6 & 2.7 \\
\hline
\end{tabular}

budgets are shown in Table 2 for the SOM simulation. This short lifetime has implications for our results, especially the relations between deposition and loading in our simulations. However, the preponderance of large particles is consistent with observations and our understanding of dust particle production [Grini and Zender, 2004].

[34] Use of the same vegetation, but different sea surface temperatures, changes the dust source, atmospheric loading and aerosol optical depth by $<4 \%$. This is similar to the interannual variability seen in assimilated wind-based models [e.g., Mahowald et al., 2003]. Changing from T42 to T85 (increasing the horizontal resolution) reduces the source by $12 \%$ and the loading and optical depth by $20 \%$. In the SOM-BASE simulation, we use the BIOME3 vegetation for the current climate to calculate the dust entrainment to the atmosphere, instead of the satellite-based vegetation, which is known to underestimate the bare ground fraction [Bonan et al., 2002]. This increases the source by $6 \%$ and the atmospheric loading and optical depth by $25 \%$. Thus the model is more sensitive to these vegetation changes or resolution than to the sea surface temperature boundary condition used here.

[35] A comparison of the annually averaged optical depth from desert dust in the model to MODIS satellite-retrieved optical depths from the year 2001 (http://modis-atmos. gsfc.nasa.gov) shows that the model yields a good regional distribution of mineral aerosol optical depths (Figure 1). The satellite retrievals include all aerosols, thus key comparisons are in those the regions where dust dominates (North Africa, Northern Tropical Atlantic Ocean, Arabian Sea). The optical depths retrieved from MODIS are not available over desert regions, and may be biased in areas close to deserts. The optical depth maxima simulated in the model tend to be shifted southward over the North Atlantic compared with MODIS. The model optical depths are too large over the North Atlantic and too small over the Arabian Sea, compared with the MODIS retrievals, although comparisons to the AVHRR satellite retrievals for periods in1989-1991 [Husar et al., 1997] show better agreement over the tropical North Atlantic (not shown). We note that in this case the geomorphology-based soil erodibility factor from Zender et al. [2003b] results in the African dust sources dominating, while in the recent version of the GISS model, the dominant sources span across Africa and Asia [Cakmur et al., 2006]. This highlights the importance of the vegetation, soil erodibility and atmospheric model in determining dust sources.

[36] Comparisons between dust deposition from model simulations (SOM-BASE) and observations from the DIRTMAP database [Kohfeld and Harrison, 2001] show that the model does a good job of capturing the six order of magnitude range in deposition rates (Figures $2 a-2 c$ ). We use this case for the current climate/modern comparison, because this is the case we will use for most of the analysis of the climate change scenarios. DIRTMAP includes modern and last glacial maximum dust deposition data from ice core measurements, marine sediment traps and marine sediment cores. While these data represent a critical comparison tool for estimates of deposition during the current and last glacial maximum climates, the deposition data shown here are not without their own problems, as discussed in more detail elsewhere [Mahowald et al., 1999; Kohfeld and Harrison, 2001; Mahowald et al., 2006]. The ice core measurements are concentrations $(\mathrm{g} / \mathrm{g})$ in each depth increment in the ice core, which must be converted to flux units to be easily compared to model values. However, flux calculations rely upon estimates of ice accumulation rate in the cores. The marine sediment trap and core data are difficult to interpret because the data are taken from sediment traps within the water column or from cores at the ocean floor, not at the surface, and ocean currents can advect dust substantially before it is deposited [Siegel and Deuser, 1997]. Most marine sediment cores are not directly dated, which adds additional uncertainty, especially since the core tops are not always sampled (similar to the problems in the terrestrial sediment record described above). Bulk marine deposition to sediment traps and cores is proportional to also ocean productivity [Bory and Newton, 2000]. Nevertheless, these data represent our best information about deposition rates for the current climate and last glacial maximum.

[37] Over a range of orders of magnitude in current/ modern deposition rates, the model agrees well with the rates estimated from observations (Figure 2c). The overall correlation coefficient between model and observed estimates of deposition from Figure 2c is 0.82 (where the log of the model and observed deposition fluxes are compared).

[38] Because the marine sediment cores (and some of the other data) represent averages over thousands of years, the data in the DIRTMAP data sets might be better compared to the preindustrial simulations conducted in this set of simulations. Nevertheless, the preindustrial climate simulations also compare favorably (Figure 3) to the DIRTMAP data set. The correlation coefficients are $0.75,0.81$ and 0.81 for the TIMIND, SOMBPI, and SOMBPIC cases. Although preindustrial dust is likely to be within $60 \%$ of current climate dust, it is not possible to discern which preindustrial scenario is most likely due to the large uncertainties in the data [e.g., Mahowald and Luo, 2003]. For the rest of this study, we compare the LGM to the current climate, not to the preindustrial climate. 


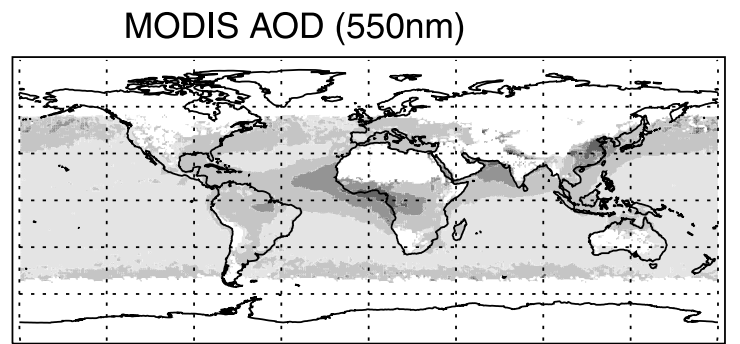

AMIP

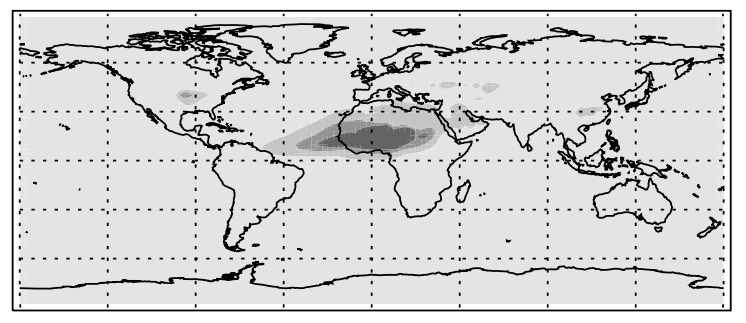

SOM-BASE

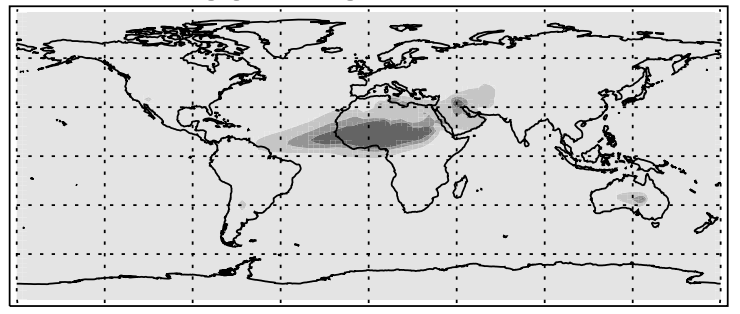

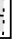

SOM-TIMIND

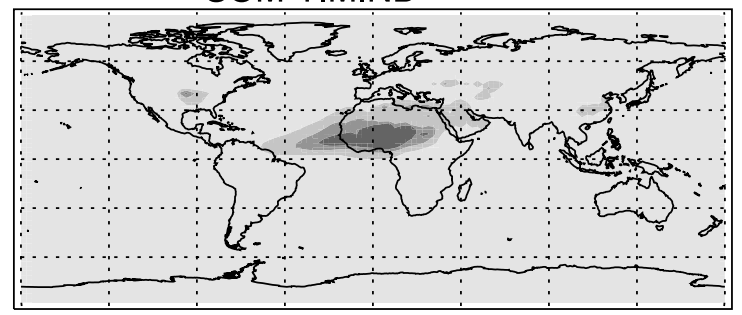

T85

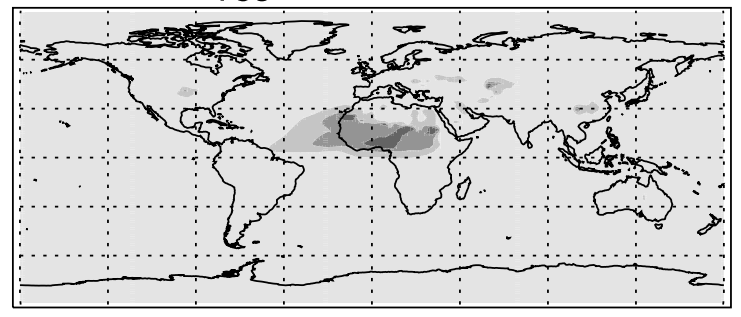

\subsection{5}

0.30

0.45

Figure 1. Aerosol optical depth from the MODIS satellite (a) at 550nm for the year 2001 (http:modisatmos.gsfc.nasa.gov). Also shown are model calculations for optical depth from the SOM-TIMIND (b), AMIP (c), T85 (d), and SOM-BASE (e) simulations (descriptions of the cases are in section 2.2 of the text).

[39] Comparisons between the modeled seasonal variations in concentration or optical depth and observations suggest that the model can capture only some of the seasonal variability in dust (online auxiliary material), similar to previous general circulation model-based studies [e.g., Woodward, 2001]. This is due to the biases in precipitation and winds in the physical model, because similar parameterizations using assimilated winds (combination of model and observations) are able to simulate the seasonal cycle [e.g., Mahowald et al., 2002; Zender et al., 2003a; Luo et al., 2003; Mahowald et al., 2003]. Generally speaking, different versions of the model compare reasonably well with observations, with some versions doing better at some stations than others (online auxiliary material).

\section{Climate Change Simulations}

[40] Vegetation changes may play an important role in dust source changes under different climates because vegetation cover affects sediment availability, roughness height and other factors [Mahowald et al., 1999; Harrison et al., 2001; Mahowald and Luo, 2003]. In order to incorporate the response of vegetation to the different climates, we use the BIOME3 equilibrium vegetation model [Haxeltine and Prentice, 1996], similar to previous studies [Mahowald et al., 1999; Mahowald and Luo, 2003]. We conduct these simulations both with carbon dioxide fertilization of plants (BASE-CO2) and without it (BASE). The changes in climate that occur in these model simulations are shown elsewhere and not repeated here [Kiehl et al., 2006; OttoBliesner et al., 2006; Mahowald et al., 2006]. In Figure 4a we show the difference between using the satellite-based vegetation from the default community land model vegetation (TIMIND-solid line) and the BIOME3 vegetation for the current climate (SOMB-dotted line). We note that there is a large difference at high latitudes in the unvegetated region that could be sources that do not translate into differences in the optical depths (seen in Figure 1) because these high latitude areas are too moist to be sources much of the year. For the last glacial maximum (LGM), preindustrial (PI), and doubled-carbon dioxide climate (DCO2), the solid line incorporates temperature, precipitation and cloudiness changes (BASE), while the dotted line also includes carbon dioxide fertilization changes (BASE-CO2). The changes in source areas for the dust sources can be seen to be variable 
a.

Dust deposition $\mathrm{g} / \mathrm{m} 2 /$ year BASE-CUR

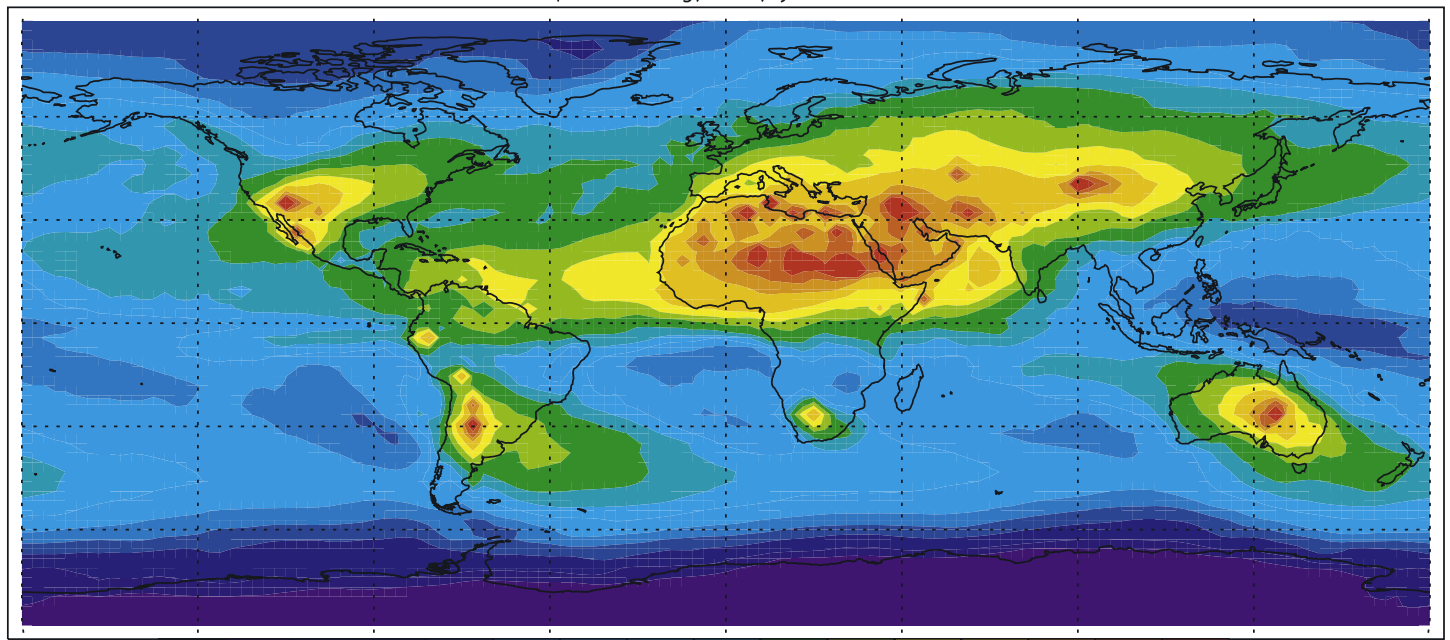

b.

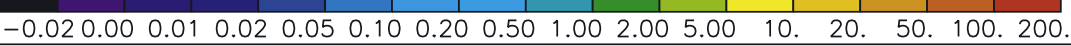

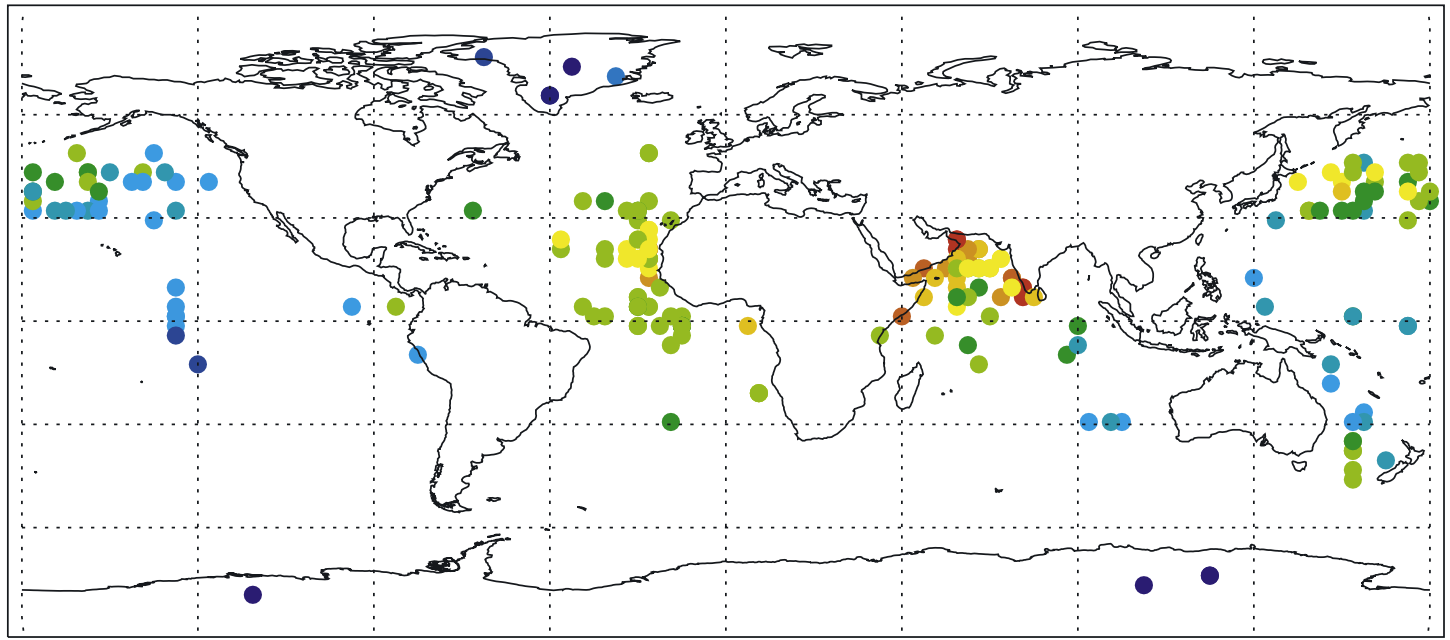

C.

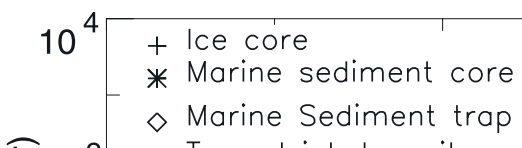

बิ $10^{2}-\triangle$ Terrestrial deposit

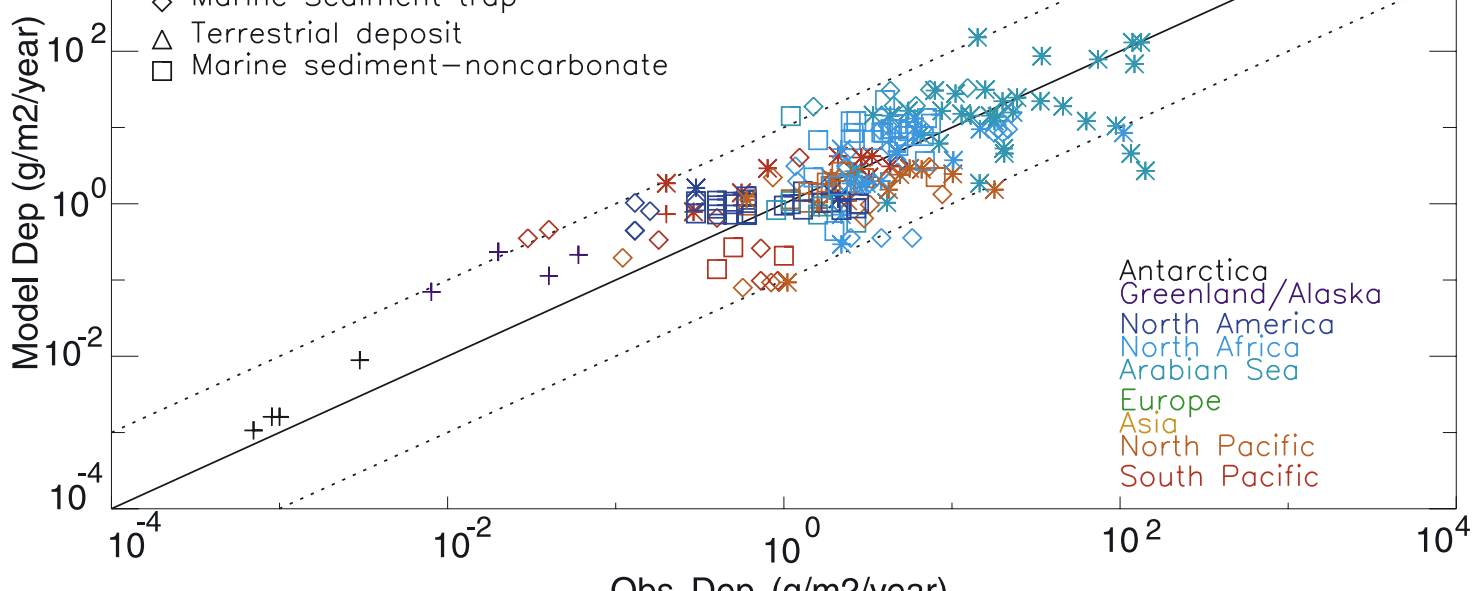

Obs. Dep. (g/m2/year)

Figure 2. Dust deposition comparisons between the model (a) and observational estimates from DIRTMAP [Kohfeld and Harrison, 2001] (b) and a scatterplot between the model and observations (c). 

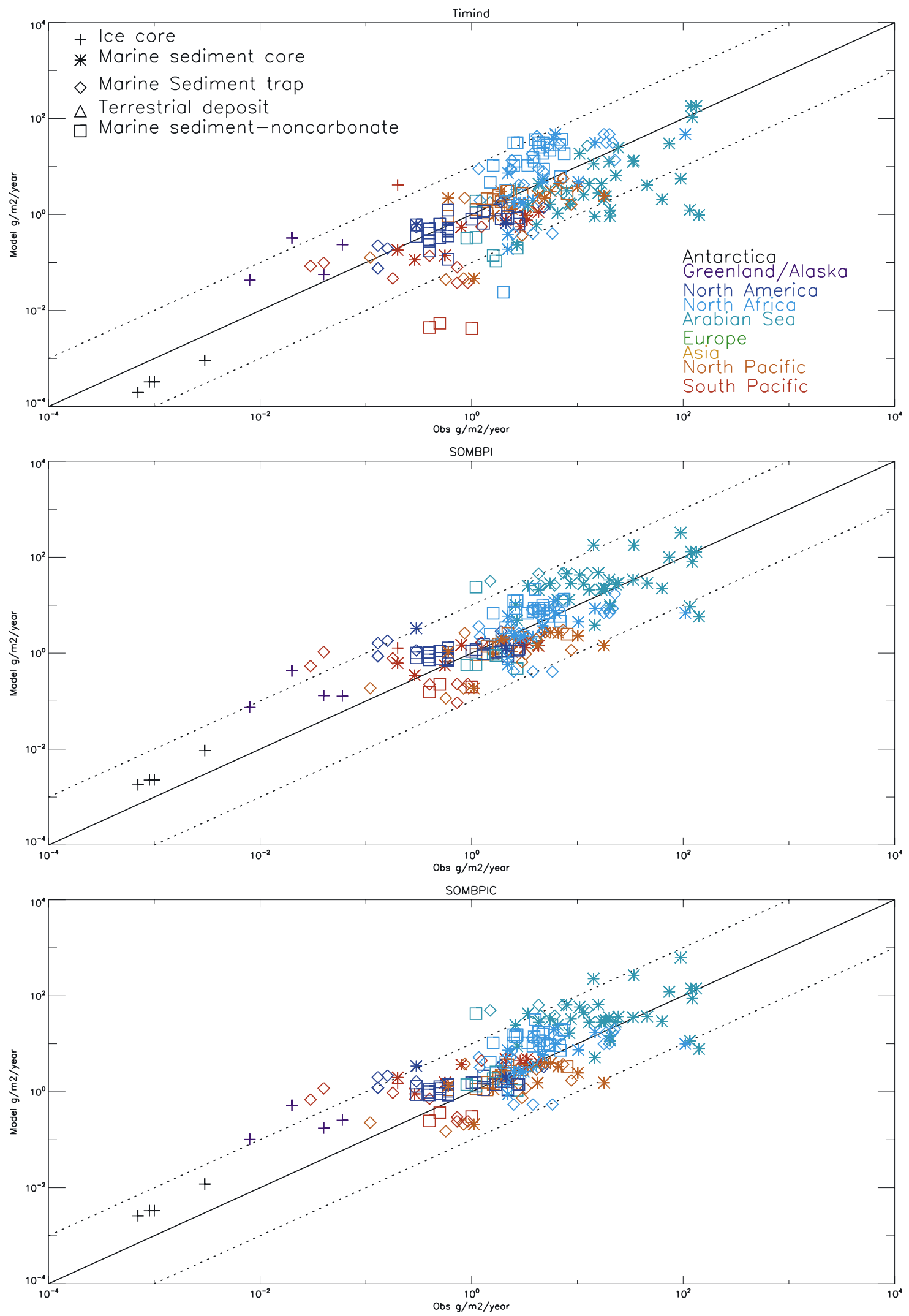

Figure 3. Scatterplot of dust deposition comparisons between model and observations in $\mathrm{g} / \mathrm{m} 2 / \mathrm{year}$ (similar to Figure 2c) for the TIMIND (a), BASE (b), and BASE-CO2 (c) case for the preindustrial. Observations are the same as in Figure 2. 

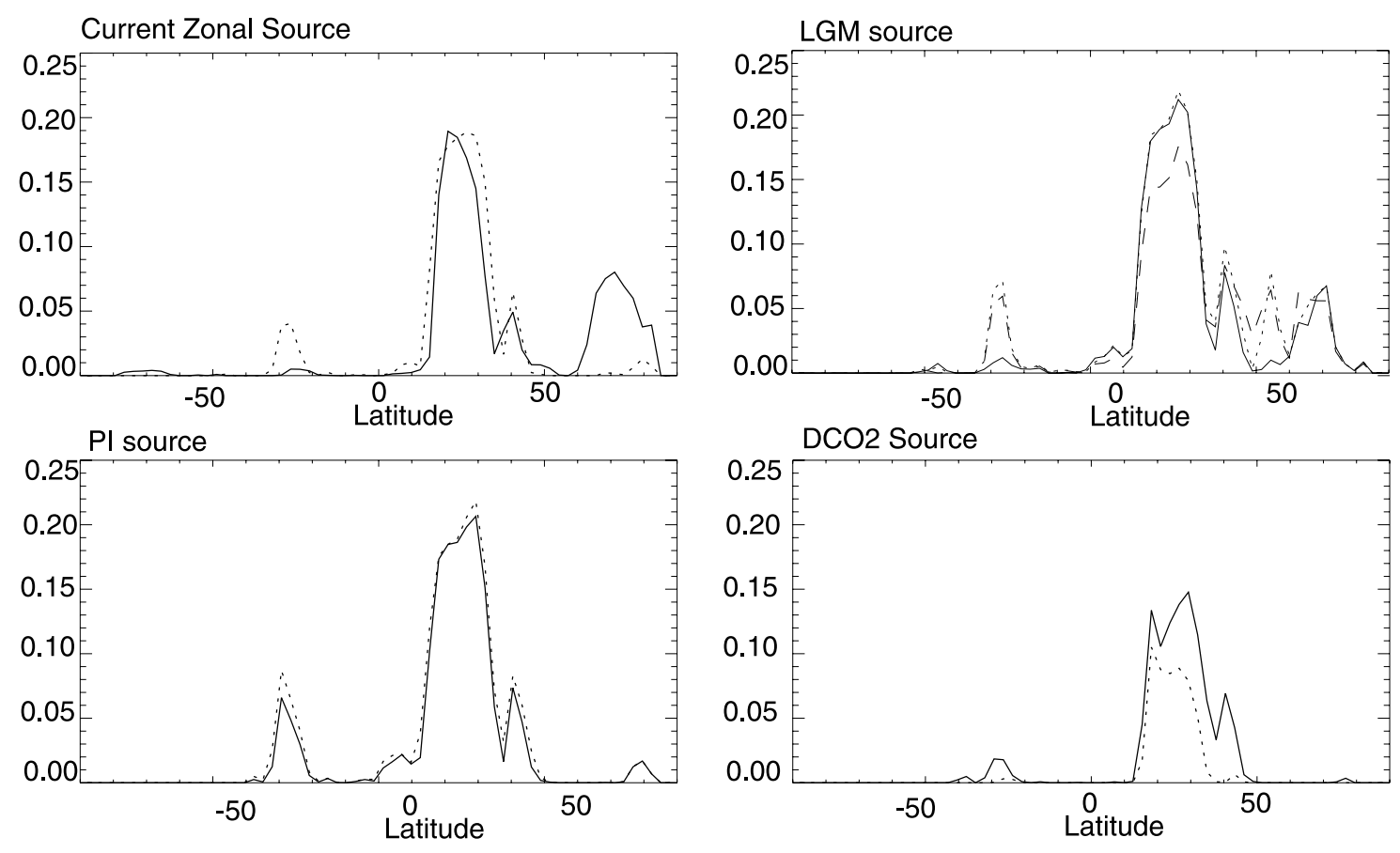

Figure 4. Zonal average dust source areas for the current climate (a). Solid line shows source area using the satellite based vegetation used by default in the Community Land Model (CLM3), while the dotted line uses the results of the BIOME3 equilibrium vegetation model for the current climate. For the (b) last glacial maximum (LGM), (c) preindustrial (PI), and (d) doubled-carbon dioxide (DCO2) cases, the solid line represents the source area when precipitation, temperature and cloudiness changes are included in the calculation, while the dotted line adds in carbon dioxide fertilization of vegetation. For the LGM case, we also include the tuned case 1 (dashed line).

by latitude. Nevertheless, as we move to higher carbon dioxide concentrations, the BASE-CO2 cases (dotted lines) have less source area due to the effect of carbon dioxide fertilization, and have larger source areas in lower carbon dioxide climates (e.g., LGM) than if carbon dioxide fertilization is not included. Figure $5 \mathrm{a}$ shows the globally averaged response of the source area to changes in climate for the different cases considered here. All cases are shown relative to the current climate for the rest of this paper. Overall, the carbon dioxide fertilization effect causes the greatest change in source area. The change in vegetation simulated for the last glacial maximum is qualitatively similar to previous studies [Mahowald et al., 1999], although the change in dust sources is smaller in magnitude (here the change is $+35 \%$, while in Mahowald et al. [1999], the change was close to $+100 \%$ ). This difference in vegetation response to climate model simulation is probably due to the difference in the average precipitation over land, which decreased by $-0.5 \mathrm{~mm} /$ day in the ECHAM3 simulations, but only by $-0.4 \mathrm{~mm} /$ day in our simulations, as well as differences in the spatial distribution of the precipitation changes. The difference in source areas simulated here based on different climate model responses to climate change highlight the sensitivity of results to the model configuration, as noted more fully in previous studies (e.g., http://www-lsce.cea.fr/pmip).

[41] How the globally averaged dust loading changes with climate is different in the different scenarios (Figure 5b). It is worth noting that inclusion of changes in source area is required in order to have changes larger than $34 \%$ in dust loading, similar to results in Mahowald et al. [1999] and Mahowald and Luo [2003], in contrast to Werner et al. [2002], where surface winds play a large role. In the case where the dust vegetation is held constant (TIMIND) the model simulates changes in dust loading of $+34 \%,-3 \%$ and $+2 \%$ in the LGM, preindustrial and future climate, respectively, relative to the current climate. Including changes in vegetation from precipitation, temperature and cloudiness (BASE) changes dust loading by $+53,+12$ and $-31 \%$ in the LGM, preindustrial and future climate, respectively. The biggest changes occur when carbon dioxide fertilization is included, where dust loading changes by $+92 \%,+33 \%$ and $-60 \%$. Figure 6 shows optical depth as a result of climate changes for each of the cases. Expansion of dust loading in the tropics as well as in midlatitudes is seen as the dust increases, consistent with the increases in source area shown in Figure 4. Changes in dust between preindustrial, current climate and future climate are similar to previous simulations with the CSM1.0 when human land use change is neglected [Mahowald and Luo, 2003].

[42] The vertical distribution of desert dust for the SOM current climate case (using the TIMIND) source, and the changes due to climate change using the TIMIND source are shown in Figure 7. Changes in the zonally averaged vertical distribution of desert dust are large (0.60), even when the globally averaged changes are $34 \%$ or less for the TIMIND case. However, the differences in vertical transport of constituents in this model from climate change are 
a

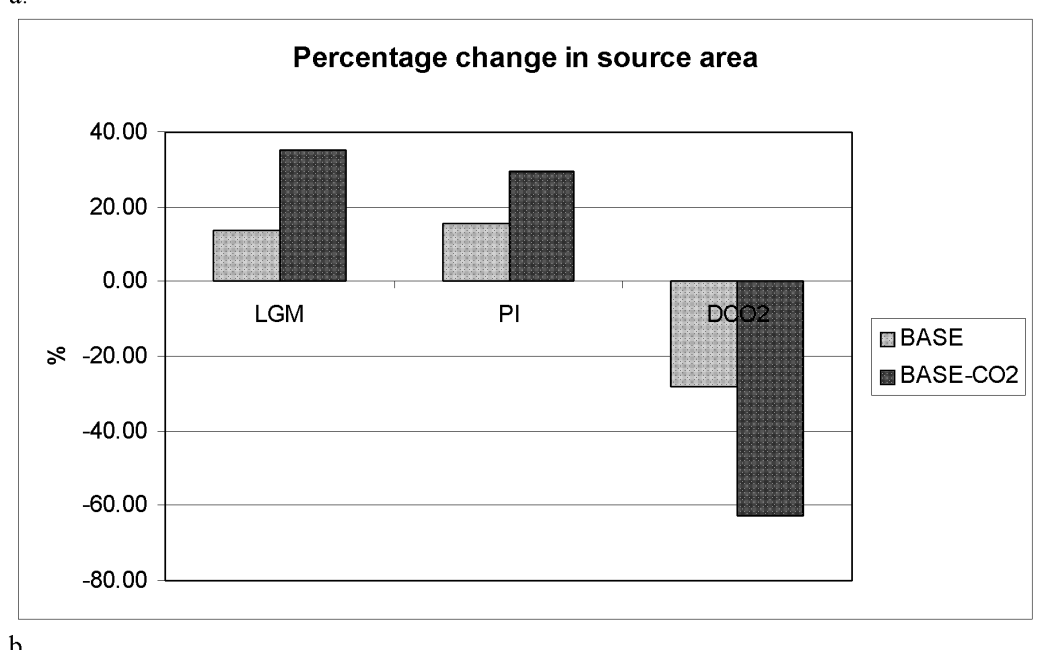

b.

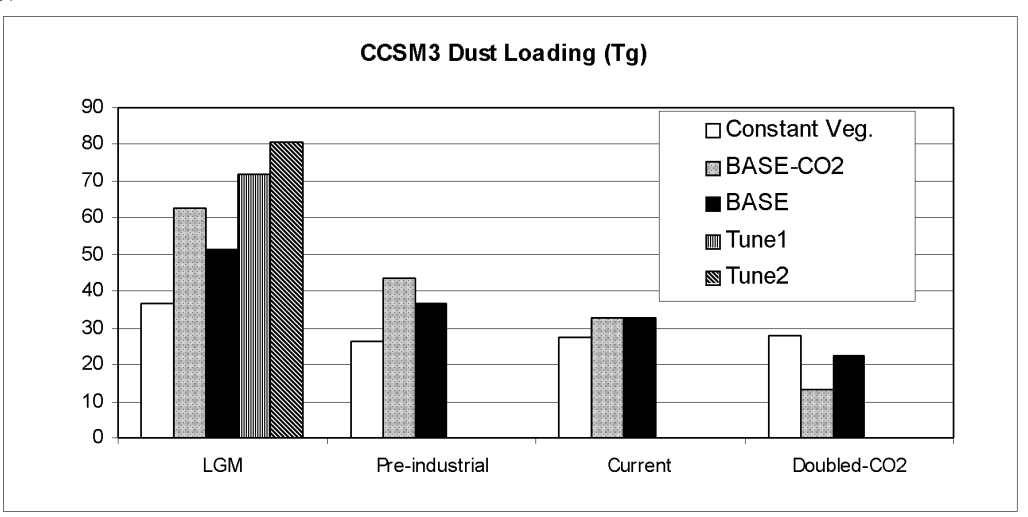

Figure 5. Globally averaged change in dust as a response to climate for the source areas (m2) (a) and dust loading $(\mathrm{Tg} / \mathrm{m} 2)$ (b) for the LGM, PI, and DCO2 climates using the TIMIND, BASE, BASE-CO2, and tuned cases (for the LGM).

smaller than the differences due to changes in the dynamics in the model [Rasch et al., 2006], so that one should interpret these differences with caution.

\section{Last Glacial Maximum Dust}

[43] While there are limited data for dust changes in the preindustrial period [Mahowald and Luo, 2003], and of course no data for the future time period, there is substantial evidence for changes in dust deposition during the last glacial maximum. Thus, we focus on this time period for this section. We show comparisons between last glacial maximum desert dust deposition from observations and from the model simulation (BASE-CO2-LGM) incorporating changes in equilibrium vegetation from precipitation, temperature, cloudiness and carbon dioxide fertilization (Figure 8). The observations from marine sediment cores and ice cores are taken from the DIRTMAP database [Kohfeld and Harrison, 2001], while the terrestrial sediment (loess) records have been compiled for this paper (see section 3 and online auxiliary material for the data tables and references).

[44] We emphasize that the terrestrial sediment record suggests very high deposition rates in continental interiors that cannot be reproduced by the model. Especially over
North America, the model underestimates deposition rates by one to three orders of magnitude (Figure 7c). We see large underestimations in deposition rates in Europe and Alaska as well (1-3 orders of magnitude). The source distribution for the BASECO2-LGM case is illustrated in Figure $8 \mathrm{a}$, and shows that there is a source of dust in the middle of the U.S., similar to Werner et al. [2002], which is an improvement over some previous studies, which did not have a source in this region [e.g., Mahowald et al., 1999]. In our model simulations and those from Werner et al. [2002] deposition rates from this source are much less than estimates from observations. As discussed below, the sources in the Midwestern U.S. are thought to be a combination of an arid region and glaciogenic dust sources. For Siberia, Alaska, and the Pampas region of Argentina, there are nonglaciogenic dust sources simulated in our model, but they do not produce fluxes as large as those observed in the geologic record for these regions. Interestingly, these nonglaciogenic sources, derived strictly from equilibrium vegetation model simulations, are much larger in Mahowald et al. [1999] than in the present model, highlighting how the modeled dust flux results are sensitive to the climate model and/or dust model used for the simulations. For at least two of these regions, geologic evidence suggests there could have been both glaciogenic or arid-vegetation-derived (i.e., 

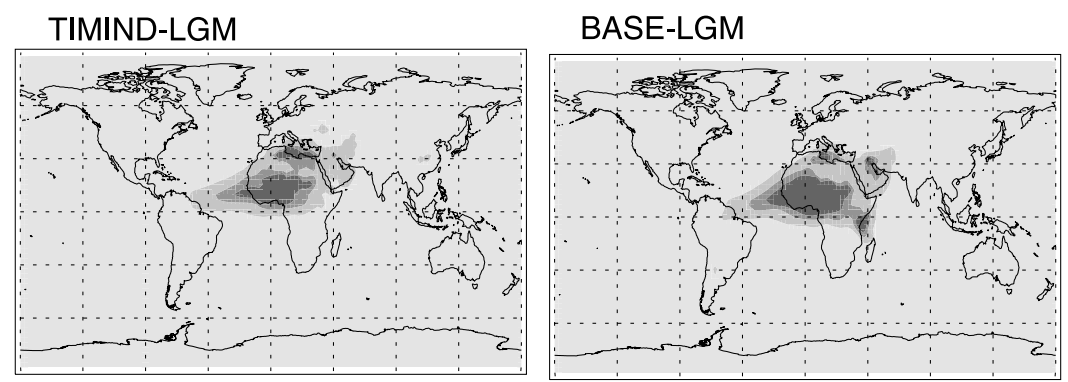

BASECO2-LGM
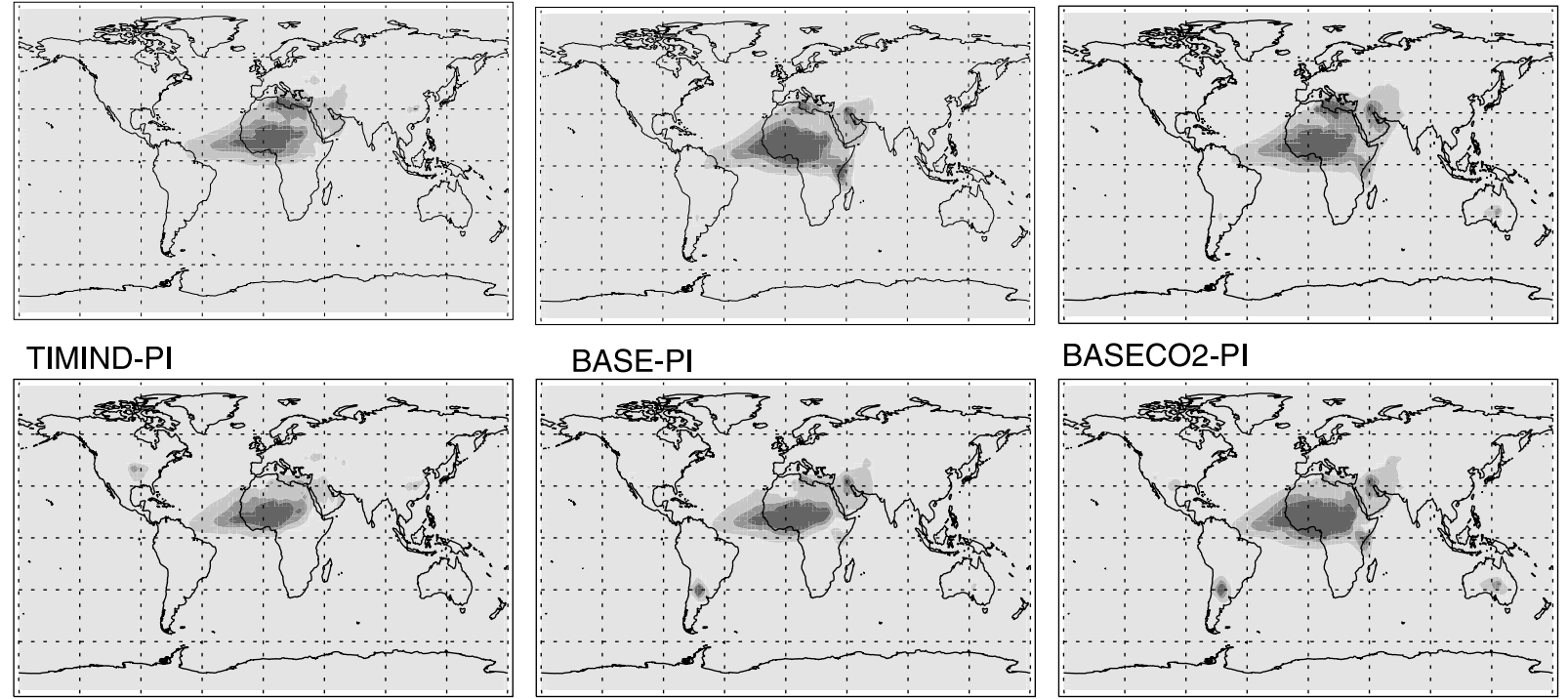

TIMIND-DCO2

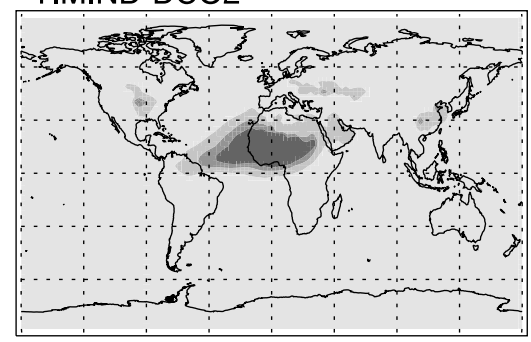

BASE-PI

BASECO2-PI

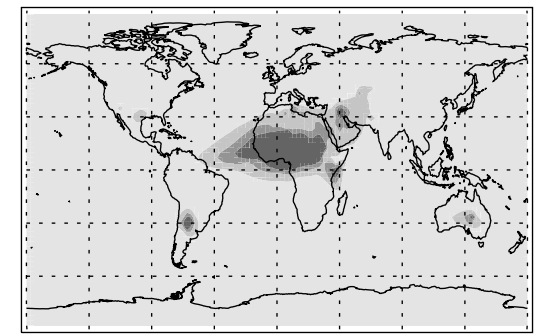

BASECO2-DCO2
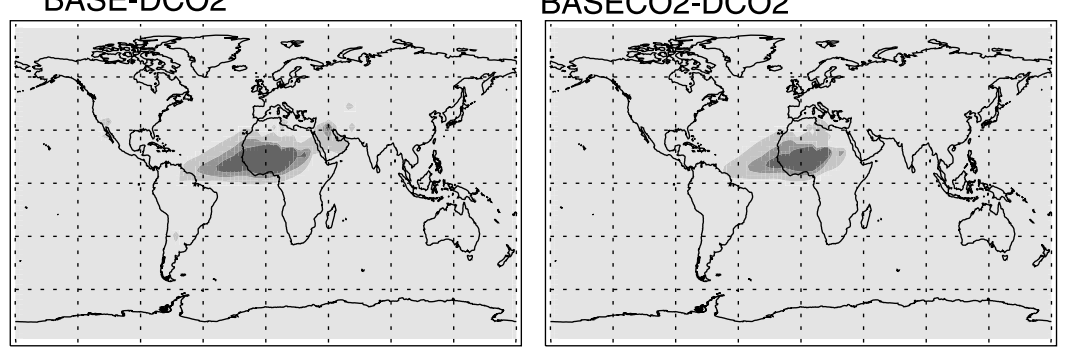

\subsection{5}

Figure 6. Changes in aerosol optical depth due to changes in climate for the different cases considered here for the last glacial maximum (LGM), preindustrial (PI), and doubled-carbon dioxide (DCO2) climates.

nonglaciogenic) dust sources. In both Alaska and South America, glaciers were more extensive than now during the last glacial period, which could obviously generate more glaciogenic silt. However, as simulated in our model, both regions were also colder, drier, and more sparsely vegetated than present during the last glacial period [Prieto, 1996; Edwards et al., 2000; Ager, 2003], which could enhance the supply of nonglaciogenic dust.

[45] During the last glacial maximum, continental ice sheets generated extraordinary amounts of silt-sized particles. The sources used for our simulation shown so far in this paper are based on equilibrium vegetation, but without adjustments for substantial glaciogenic sources of dust along the edges of the ice sheets. In order to account for these glaciogenic sources, we include six regions with glaciogenic sources in separate dust simulations, using the same source, deposition and transport parameterizations. We include glaciogenic sources in Europe, Siberia, South America (Pampas region) and North America (Mississippi River basin, Alaska and Idaho). Following Frechen et al. [2003], we assume a broad region in Europe that could have been a glaciogenic source of dust, south of the Scandanavian ice cap, with major rivers such as the Rhine and Danube as the suppliers. In the Pampas region of South America, we assume that the glaciogenic source is near the Colorado and Negro River basins [Zárate, 2003]. For the Siberian region, we assume that the lowland river basins which serve as the outflow from the Yakutia region, e.g., Lena, Kroma, and Indigirka River Basins are primary dust sources (see references in online auxiliary material). The Mississippi, Missouri, Illinois and Ohio River valleys in the US were the main carriers of glacial outwash from the Laurentide-ice sheet and thus a source of loess [Muhs and Bettis, 2003]. In addition to the vegetation-based source in Alaska, it is likely that the Yukon and Tanana River basins were glacial outflow regions, and thus sources of dust to the atmosphere [Muhs et al., 2003a; Muhs and Budahn, 2006]. The Snake River Valley in Idaho is thought to have been a region of loess that was active as a dust source during this time period [Pierce et al., 1982]. Additionally, the model has an equilibrium vegetation source in the Badlands area of South Dakota, Nebraska, 

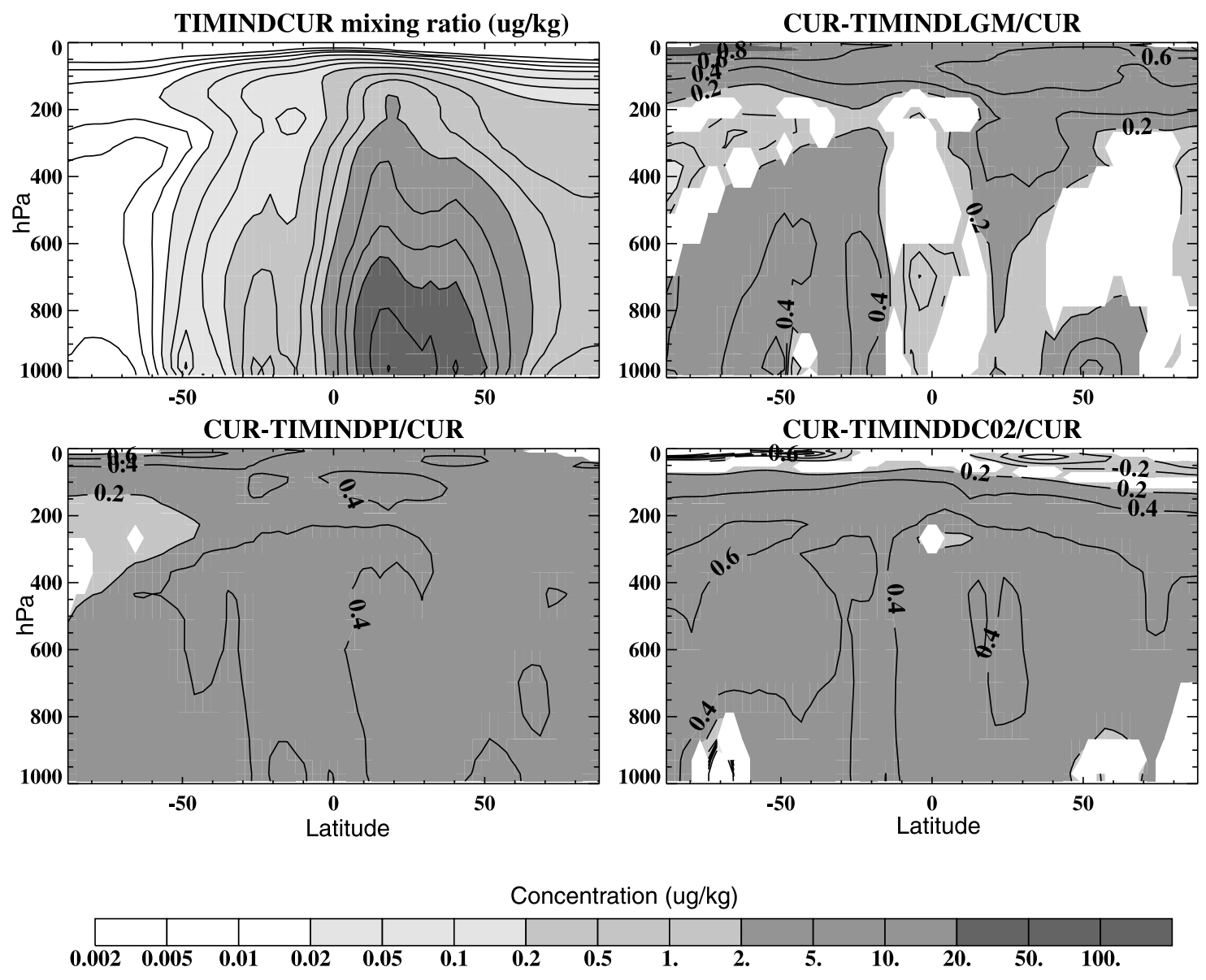

Ratio

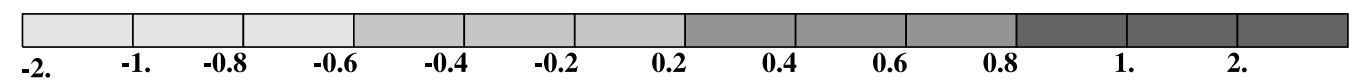

Figure 7. Zonally averaged vertical distribution of dust concentrations for the current climate (TIMIND-CUR), and the differences between the different climates relative to the current climate for the LGM, PI, and DCO2 climate for the TIMIND source case.

Wyoming and Colorado, but this source is not large enough to match available observations, so we add in an additional source in this region, which we include in the tuning described below. This region is thought to be a source due to its aridity and lack of vegetation so the CCSM3/BIOME3 predicted dust source area is not consistent with available observations [Roberts et al., 2003; Aleinikoff et al., 1999]. These source regions are shown in Figure $9 \mathrm{~b}$. Other source regions appear to be roughly consistent with the geologic record. Although there are large areas of loess deposits in China dated to this time period, it is not clear whether these are due to aridity and/ or glaciogenic sources [Sun, 2002a, 2002b]. Our model appears to match available sediment records in this region without a glaciogenic source. Note that because of our inability to model glaciogenic sources, we are using the data to match the model to the data, and thus inferring the strength of these sources from available data.

[46] We vary the magnitude of the 8 sources $(7$ described above and one from BASE-CO2-LGM) in order to achieve the best fit with the data shown in Figure $8 \mathrm{~b}$ using two different cost functions, shown below.

$$
\begin{aligned}
\text { Cost_Function_1 }= & 10 * \sum_{\text {icecores_obs }}\left(\log \left(\text { dep }_{\text {model }}\right)-\log \left(d e p_{\text {obs }}\right)\right)^{2} \\
& +\sum_{\text {marine }+ \text { terrestrial_obs }}\left(\log \left(d e p_{\text {model }}\right)\right. \\
& \left.-\log \left(\text { dep }_{\text {obs }}\right)\right)^{2} \\
\text { Cost_Function_2 }= & \sum_{\text {all_obs }}\left(\log \left(d e p_{\text {model }}\right)-\log \left(\text { dep }_{\text {obs }}\right)\right)^{2}
\end{aligned}
$$

where dep $\mathrm{obs}_{\text {is }}$ the observed deposition, and dep $\mathrm{p}_{\text {model }}$ is the modeled deposition at the same location as the observation, which is given calculated at each location using the following equation:

$$
d e p_{\text {model }}(x, y)=\sum_{j=1,9} a_{j} d e p_{j}(x, y)
$$


a.

Dust deposition $\mathrm{g} / \mathrm{m} 2 /$ year BASECO2-LGM

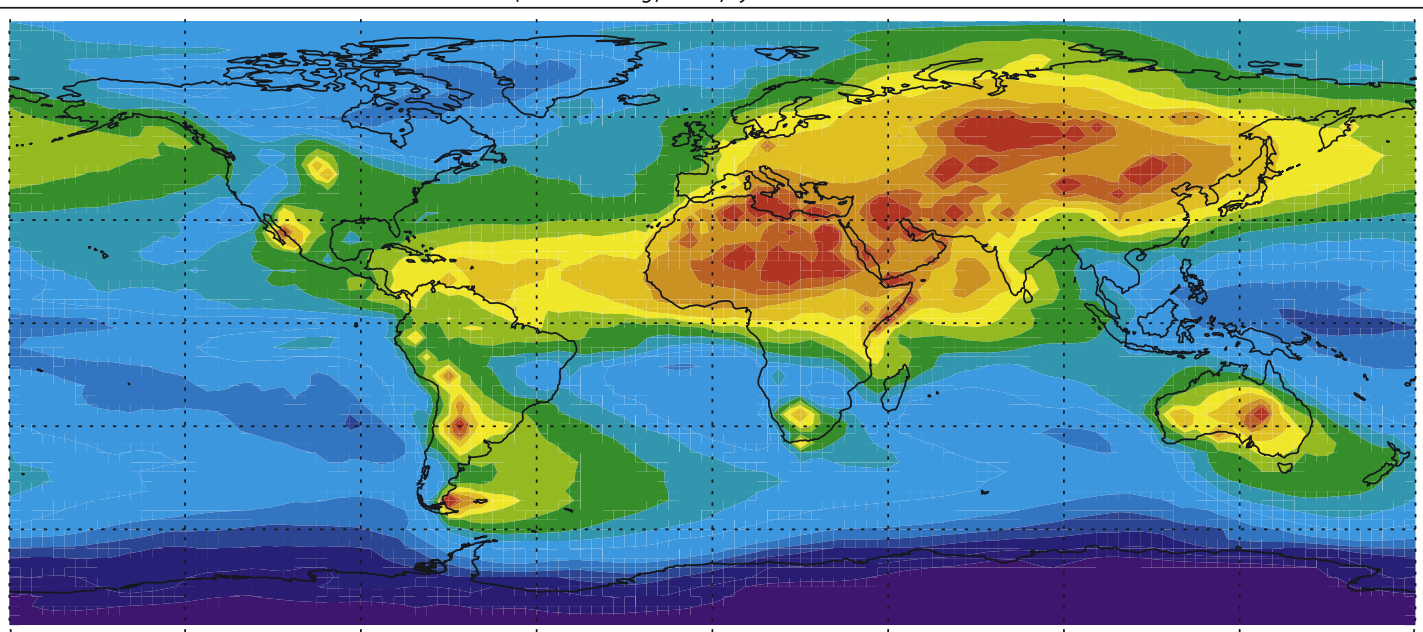

b.
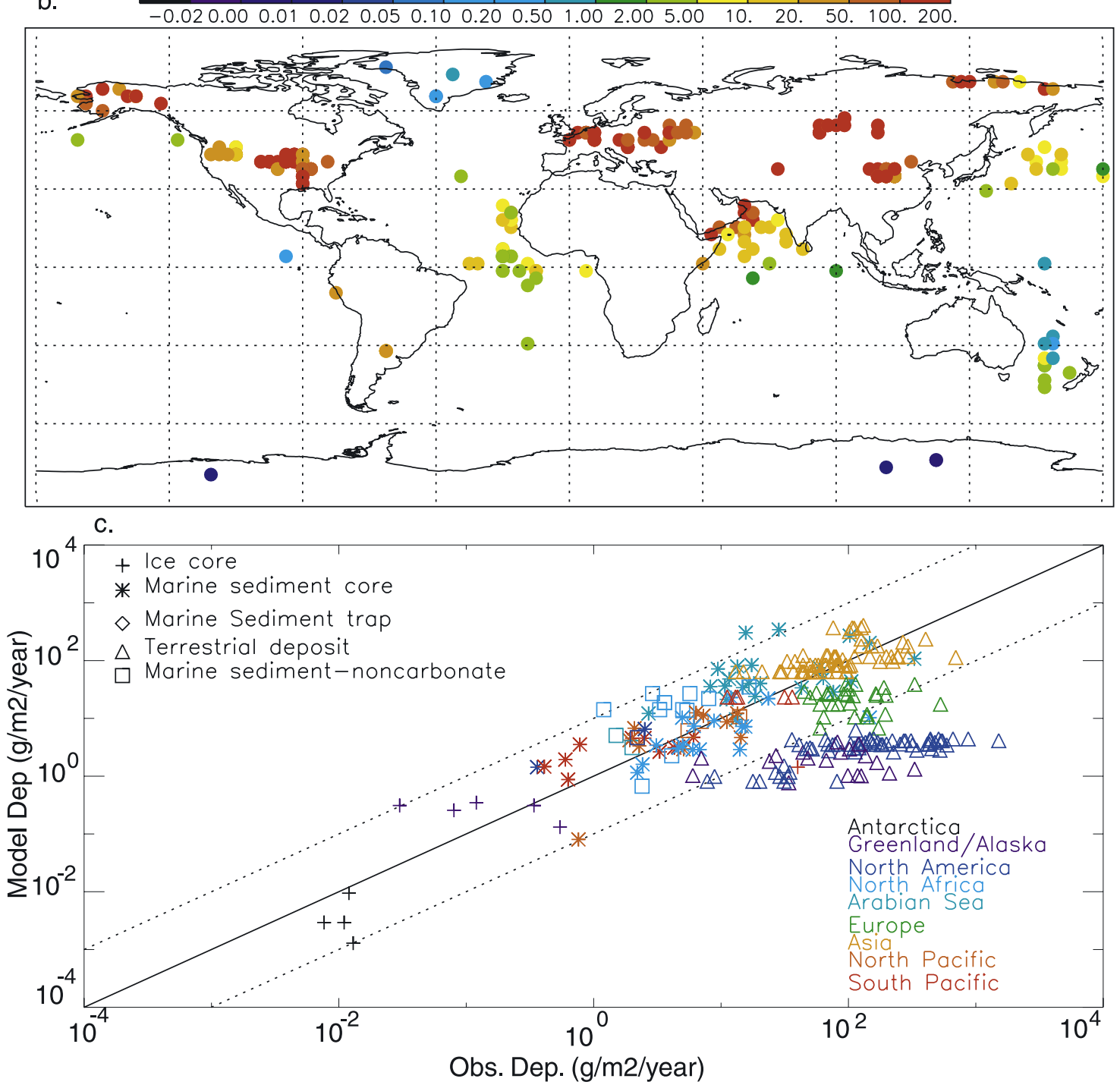

Figure 8. Comparison between dust deposition in the BASECO2-LGM case to observations (similar to Figure 2). In addition to the DIRTMAP observations, terrestrial sediment records for deposition are included in the comparison (see online auxiliary material for data). 

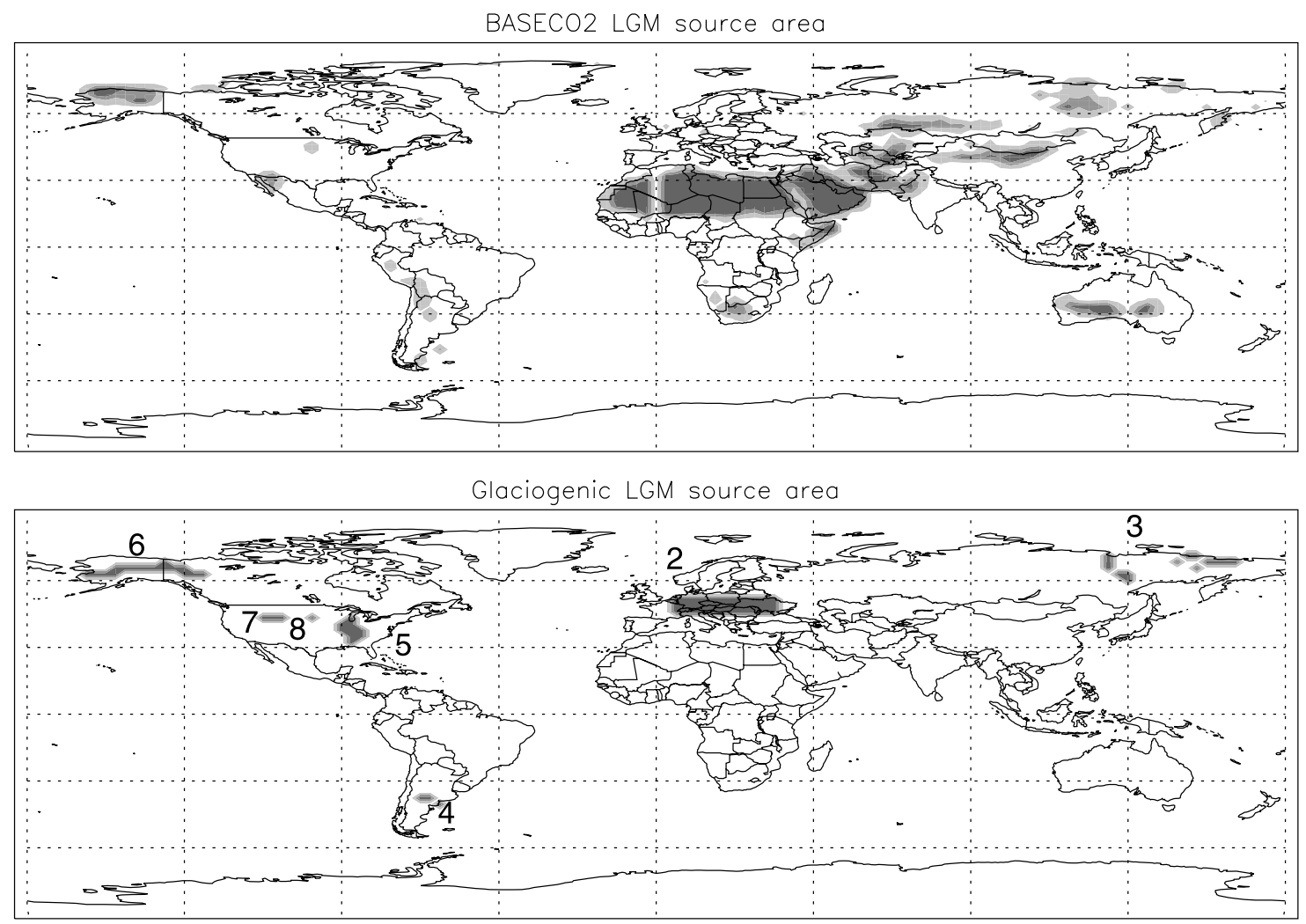

TUNE1 LGM source area
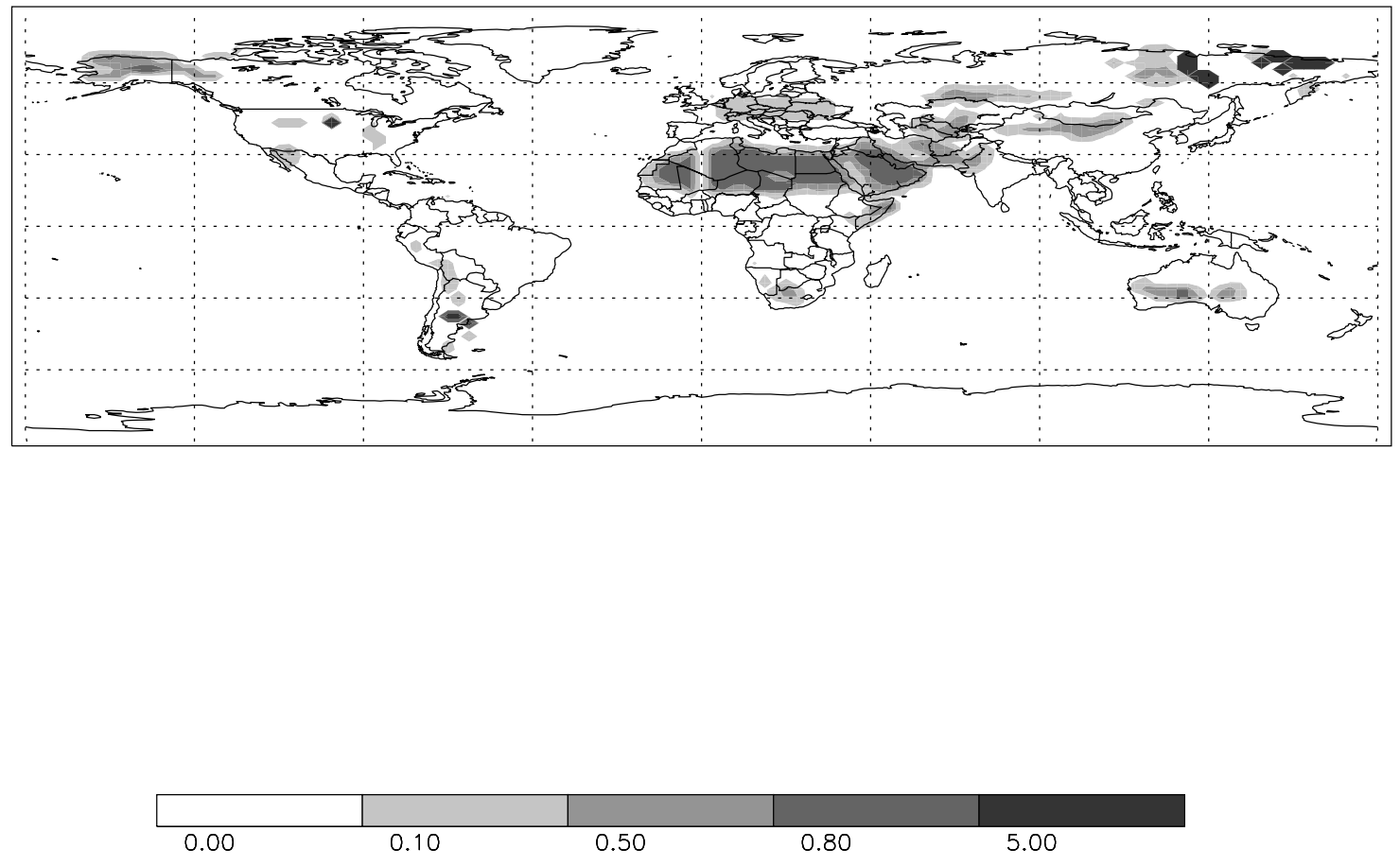

Figure 9. Source areas used for the last glacial maximum simulations for BASECO2-LGM (a), the glaciogenic sources (b), and TUNE1-LGM (c). In Figure 9b the numbers refer to the source areas in Table 3 and are Europe (2), Siberia (3), Pampas (4), Mississippi River Basin (5), Alaska (6), Idaho (7), and the Midwestern U.S. Badlands (8). 
Table 3. Source Strengths for the Optimized Sources

\begin{tabular}{|c|c|c|c|c|c|c|}
\hline & & $\begin{array}{c}\text { Tune } 1 \\
\text { Coefficient }\end{array}$ & $\begin{array}{c}\text { Tune } 2 \\
\text { Coefficient }\end{array}$ & $\begin{array}{c}\text { Unit } \\
\text { Source } \\
\text { Strength, } \\
\text { Tg/year }\end{array}$ & $\begin{array}{c}\text { Tune1 } \\
\text { Source } \\
\text { Strength, } \\
\text { Tg/year }\end{array}$ & $\begin{array}{c}\text { Tune2 } \\
\text { Source } \\
\text { Strength, } \\
\text { Tg/year } \\
\end{array}$ \\
\hline 1 & BASECO2 & 0.83 & 0.73 & 9924 & 8241 & 7290 \\
\hline 2 & Europe & 0.31 & 0.55 & 942 & 288 & 515 \\
\hline 3 & Siberia & 564 & 1209 & 6 & 3320 & 7118 \\
\hline 4 & Pampas & 8.04 & 4.13 & 241 & 1935 & 994 \\
\hline 5 & Mississippi River Basin & 0.12 & 0.03 & 782 & 92 & 22 \\
\hline 6 & Alaska & 0.61 & 0.60 & 64 & 39 & 38 \\
\hline 7 & Idaho & 0.45 & 0.56 & 38 & 17 & 21 \\
\hline \multirow[t]{2}{*}{8} & U.S. Badlands & 30.1 & 91.9 & 28 & 841 & 2563 \\
\hline & Total & & & & 14773 & 15997 \\
\hline
\end{tabular}

where $a_{j}$ is coefficient to multiply each of the modeled sources and $\mathrm{dep}_{\mathrm{j}}$ is the modeled value of deposition at each spot for each of the 9 sources modeled (LGMBASECO2, 6 glaciogenic sources (Europe, Siberia, South America, Mississippi River basin, Alaska, and Idaho) and U.S. Badlands source, shown in Figure 9). For the LGMBASE$\mathrm{CO} 2$ case, $\mathrm{a}_{0}$ is 1 , and all other $\mathrm{a}_{\mathrm{j}} \mathrm{s}$ are 0 . For Tune 1 and Tune2, the values of $a_{j}$ are solved using the equations above for Tune1 and Tune2, using MATLAB fminsearch algorithm which uses a simplex search method (to make sure all values are positive, we add a large number to the cost function if an $a_{j}$ is negative). We match 266 observations of deposition in the last glacial maximum by varying 9 source magnitudes $\left(a_{j} s\right)$. The values of the $a_{j} s$ can vary from 0 to quite large (800+), giving us effective source strengths that are much larger than the 1.0 assumed for the optimum potion in a topographic low (Table 3 ).

[47] In the first cost function (Tune 1), all observations have equal weight, except for ice core measurements which have 10 times the weight of other observations, while in the second cost function, all observations have equal weight (Tune 2). The rationale for weighting the ice core measurements more than other measurements is that the uncertainty in dust deposition fluxes from ice core measurements is probably smaller than for other observations. Additionally, ice core measurement is probably representative of a larger region than for other observations. The downside to this approach is that the model errors will also be larger farther from the observations, but since we want to get large scale distributions and depositions correct, we will be compensating for model errors with our inversion as well. The assumption that ice core data is worth $10 \mathrm{x}$ other types of data is arbitrary, but reasonable. An optimization algorithm is used to vary the magnitude of the sources to minimize the value of the cost function. The result of tuning based on equally weighting all observations (Tune 2) has larger Northern Hemisphere sources and smaller Southern Hemisphere sources than weighting ice cores more heavily (Tune 1 ). Figure $5 \mathrm{~b}$ shows the strength of the dust loading for the two tuning cases. We think that the first optimization (Tune 1 ) is scientifically more justifiable, and use it for the rest of the analysis. Note that although the major outwash river valleys represent a small area, they can have a large effective source region $(>1.0)$, meaning that they can be substantially more effective than a desert dry lake valley in producing dust. Note that if we were to have longer lifetimes, more consistent with previous studies [e.g., Luo et al., 2003; Miller et al., 2006], this would change the size of our dust sources and loadings inferred to match the depositions close to the source area.

[48] The resulting coefficients (aj), source strength without the inversion, and the resulting source strengths that best match the data for each case are shown in Table 3. This table provides information about which sources are sensitive to the exact cost function and vary by more than a factor of two depending on which is used (Siberia, Pampas, Glaciogenic Mississippi, and the Badlands). In addition it shows that some source regions need to be very effective to match the available data (Siberia and the Badlands). The large size of the coefficients imply either that these source regions are very efficient, or that the dust model is being forced to put a dust source in a location that the model naturally would not have much dust.

[49] The model tends to increase the source from the U.S. Badlands (841-2563 Tg/year) more than the Mississippi River Basin sources $(92-22 \mathrm{Tg} /$ year), such that most of the deposition to the east of the Mississippi comes from the Badlands source (not shown). This is not consistent with the geologic data, and is due to the very high deposition rates close to the Badlands, which the model cannot simulate without an additional source. These source strengths should be considered tentative, and very sensitive to both uncertain observational data and model simulations. Interestingly, although the model's mean surface winds in the LGM are easterly in the Midwestern U.S. (not shown), much of the dust generated by the Badlands source actually travels towards the east. This suggests that discrepancies between mean surface winds in models and implied by dust deposition records are because of differences in what is being compared, not failures of the models. For example Muhs and Bettis [2000] hypothesized that much loess transport in the mid-continent of North America was the result of infrequent high velocity winds rather than mean LGM winds.

[50] Adding the glaciogenic sources (Tune 1) does not add significantly to the effective dust source areas in mid latitudes and high latitudes, but this process redistributes the effective dust source somewhat (Figure 9a versus Figure 9b, and Figure $4 \mathrm{~b}$, dashed line). Minimizing the cost function also reduces the arid dust source (LGM-BASECO2) slightly, so over North Africa there is less strong of a dust source to better match the data. The strength of these sources is easier to interpret than the magnitude of the coefficient $\left(a_{j}\right)$ we are solving for, since the magnitude of the coefficient will be a 
Dust deposition $\mathrm{g} / \mathrm{m} 2 /$ year Tune1-LGM

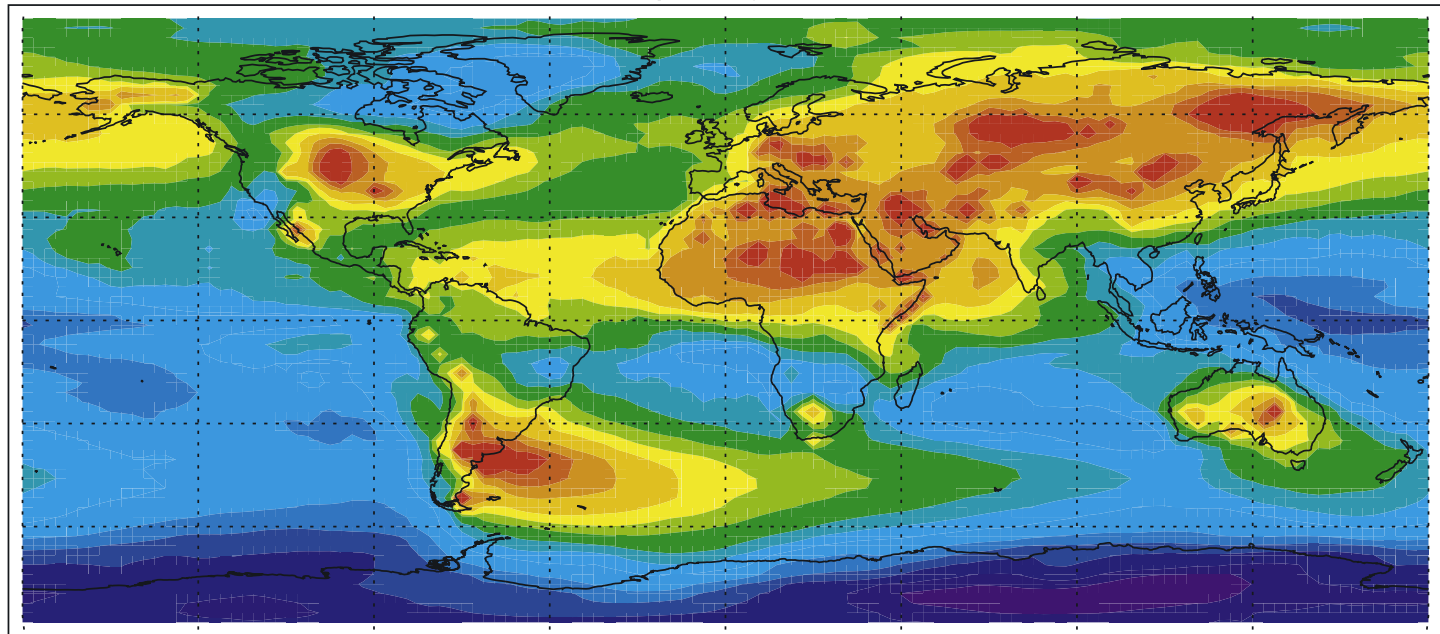

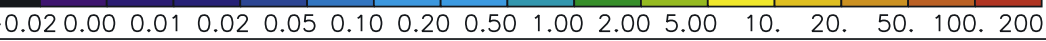
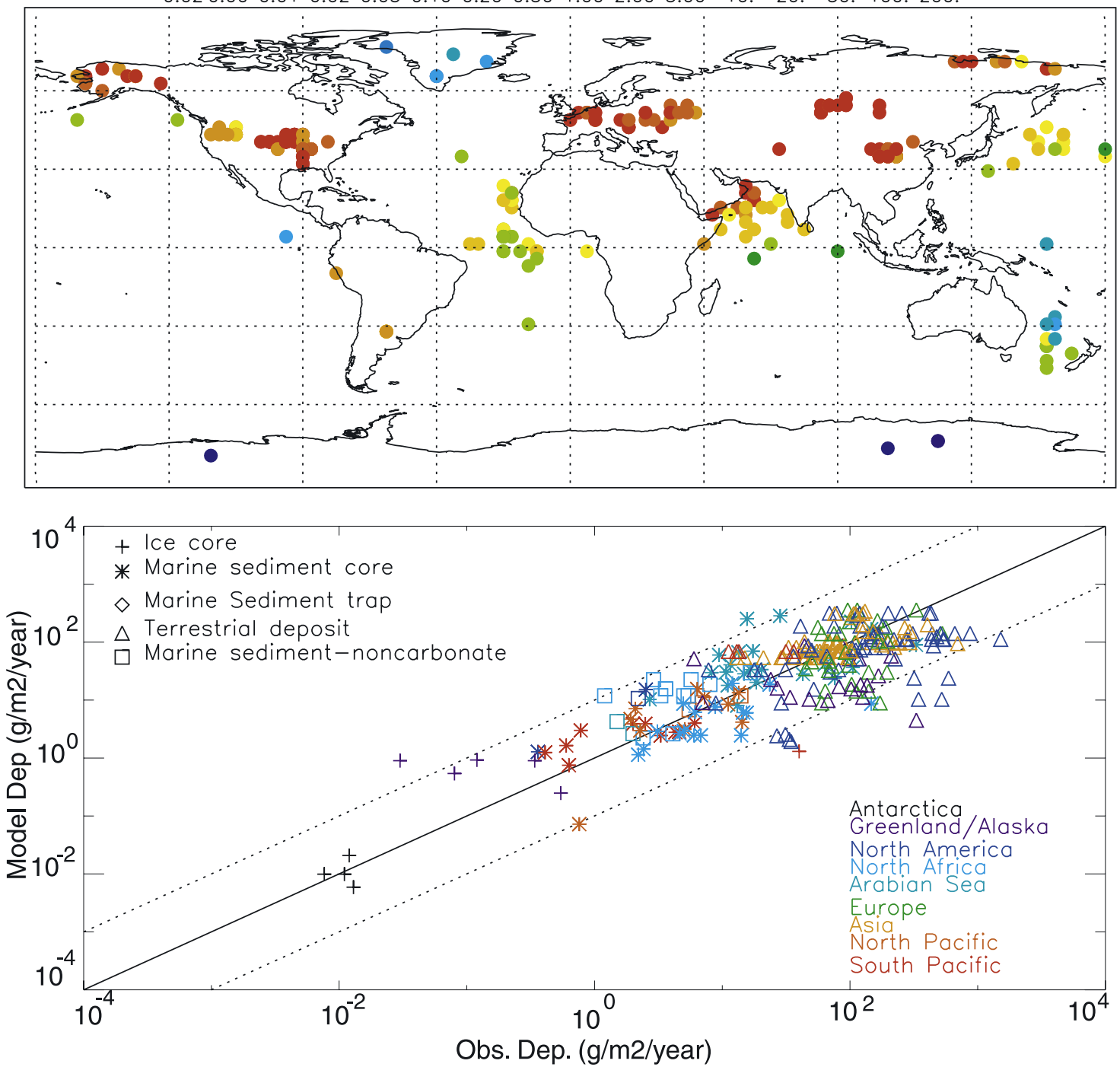

Figure 10. Similar to Figure 7, but for TUNE1-LGM case. 
function of the source area we prescribed, which is not well known, as well as the strength of the winds in the model, which will be a function of the model used.

[51] Figure 10 shows a comparison of the Tune 1 case to observations, showing the increase in deposition that results from better matching the terrestrial sediment records. The correlation coefficient between the log of the model and observed deposition is 0.81 for the last glacial maximum after the tuning using either cost function, while before tuning it was 0.50 . The ratio of dust sources or deposition in the last glacial maximum to current are 3.3, 4.1 and 2.2 for the Tune 1, Tune 2 and BASE-CO2-LGM cases, respectively. Approximately $1 / 3$ of the dust in the Tune 1 simulation comes from glaciogenic sources in the LGM. As noted previously, the source change just from vegetation is smaller in this simulation than in some previous simulations [e.g., Mahowald et al., 1999], and that would influence the fraction of dust attributed to glaciogenic sources in the LGM. In addition, studies of the sensitivity of dust models in general circulation models show large sensitivities to the choices of soil erodibility map and other parameters [e.g., Cakmur et al., 2006; Miller et $a l ., 2006]$. Thus, this fraction is likely to change with model configuration.

[52] Mineralogical and isotopic analysis has been used to suggest that Greenland ice core dust originates from Asia [Biscaye et al., 1997]. Biscaye et al. [1997] discounted North America as a source of Greenland dust primarily on the basis of mineralogy, using a limited sample size. The increase in deposition seen between the Tune 1 case versus the BASECO2 case suggests that most of the dust deposited at Greenland could come from glaciogenic or non-glaciogenic sources in the continental U.S., Alaska, or Siberia. Non-glaciogenic dust sources in the Badlands of the Great Plains have a distinctive $\mathrm{Pb}$-isotopic signature in $\mathrm{K}$-feldspar [Aleinikoff et al., 1999]. This Pb-isotope composition of Kfeldspar is not significantly different from that of bulk dust reported by Biscaye et al. [1997] in the Greenland ice cores. Nevertheless, before we can conclude that some Greenland ice-core dust may be Great Plains-derived, it is necessary to determine the bulk-mineral $\mathrm{Pb}$-isotopic composition of Great Plains dust, using the same particle size range that is found in Greenland dust, following Biscaye et al. [1997]. Similar analysis of ice cores suggest that most of the Antarctic ice core dust comes from South America [Basile et al., 1997], which is consistent with our modeling results.

[53] Recent results from the EPICA-DOME C ice core $\left(75^{\circ} \mathrm{S} 124^{\circ} \mathrm{E}\right)$ suggest that during the last glacial maximum, the fraction of dust in the fine mode (defined as $1-2 \mu \mathrm{m}$ ) increases relative to larger particles [Delmonte et al., 2004], and they attribute this to a lengthening of the transport pathway in the LGM relative to the current climate, which would preferentially remove larger particles, as they have larger gravitational settling. We also obtain an increase in the fine particle fraction $(<2.5 \mu \mathrm{m})$ in the LGM relative to the current climate. The only mechanism included in this model which preferentially removes one size distribution is the one postulated by Delmonte et al. [2004], so our model results are consistent with their mechanism. Note that stronger wind speeds in the source areas would tend to also produce smaller dust particles (called sandblasting) [e.g.,
Grini and Zender, 2004], but that process is not included in our model.

\section{Summary and Conclusions}

[54] This paper presents first results from online dust simulations in the NCAR CAM3. Comparisons to observations suggest the dust included in the model is similar in quality to previous studies [Tegen and Miller, 1998; Woodward, 2001], although optimizing the model to best match the observations could result in a better representation [e.g., Miller et al., 2006], which we plan to do in the future, using a newer version of the physical model. Based on the simulations conducted here, the current climate simulations are more sensitive to changes in resolution and vegetation than changes in sea surface temperatures, but these changes are less than $15 \%$.

[55] Desert dust responds strongly to climate, largely through changes in vegetation in this model, similar to some previous studies [Mahowald et al., 1999; Mahowald and Luo, 2003], but different from other model studies which see a stronger response to winds [Werner et al., 2002]. Similar to previous studies [Mahowald and Luo, 2003], the response of dust to carbon dioxide fertilization of arid vegetation is quite important in this model. Including changes in vegetation from precipitation, temperature and cloudiness (BASE) changes dust loading by $+53 \%,+12 \%$, and $-31 \%$ in the LGM, preindustrial, and future climate, respectively. The biggest changes occur when carbon dioxide fertilization is included, where dust loading changes by $+92 \%,+33 \%$ and $-60 \%$. All these changes are relative to the current climate.

[56] The impact of carbon dioxide fertilization on ecosystems is not yet well known. The Free Atmosphere Carbon dioxide Experiments (FACE) in an arid region suggest that as carbon dioxide increases in the future, productivity will increase, but so will invasive species [Smith et al., 2000]. Other FACE sites have seen nitrogen limitation reduce the impact of carbon dioxide fertilization [Schlesinger and Lichter, 2001].

[57] This paper includes a compilation of terrestrial sediment measurements for dust less than $10 \mu \mathrm{m}$ in diameter. Our compilation emphasizes that very large deposition rates were seen in the mid-continental regions, much of which comes from glaciogenic sources. We include possible glaciogenic source regions, and optimize the strength of these source regions to match available observations, weighting ice cores more heavily. This allows us to infer the strength of glaciogenic sources, and see their impact downwind. Including the glaciogenic sources increases the dust in the last glacial maximum from 2.1 times current climate to 3.3 times current climate, although this increase is likely to be sensitive to the model configuration used here. Note that here we are not predicting the size of these glaciogenic sources from first principals, but rather using the data to constrain the size of these sources. This substantial increase in dust, especially close to the high albedo ice sheets is likely to significantly impact the radiative effect of atmospheric desert dust. This radiative effect will be considered in a future study. In addition, increased dust flux to the world's oceans could have an impact on ocean biogeochemistry, and impact atmospheric carbon dioxide. 
[58] Acknowledgments. We would like to thank the AERONET, MODIS, and DIRTMAP principal investigators for making available data. This work was supported by NSF-OCE-9981398 and NASA-IDS (NAG59671). The National Center for Atmospheric Research is supported by the National Science Foundation. D. Muhs' work is supported by the Earth Surface Dynamics Program of the U.S. Geological Survey and is a contribution to the "Eolian History of North America" project. We appreciate the comments of R. Miller, K. Kohfeld, L. Strickland, R. Thompson, and P. Biscaye which substantially improved the manuscript.

\section{References}

Ager, T. (2003), Late Quaternary vegetation and climate history of the central Bering land bridge from St. Michael Island, western Alaska, Quat. Res., 60, 19-32.

Aitken, M. J. (1998), An Introduction to Optical Dating, Oxford Univ. Press, New York.

Aleinikoff, J. N., D. R. Muhs, and C. M. Fanning (1998), Isotopic evidence for the sources of late Wisconsin (Peoria) loess, Colorado and Nebraska: Implications for paleoclimate, in Dust Aerosols, Loess Soils and Global Change, edited by A. J. Busacca, Misc. Publ. MISC0190, pp. 124-127, Coll. of Agric. and Home Econ., Washington State Univ., Pullman.

Aleinikoff, J. N., D. R. Muhs, R. Sauer, and C. M. Fanning (1999), Late Quaternary loess in northeastern Colorado, Part II-Pb isotopic evidence for the variability of loess sources, Geol. Soc. Am. Bull., 111, 1876-1883.

Andersen, K. K., A. Armengaud, and C. Genthon (1998), Atmospheric dust under glacial and interglacial conditions, Geophys. Res. Lett., 25, $2281-$ 2284.

Antoine, P., D.-D. Rousseau, J.-P. Lautridou, and C. Hatté (1999), Last interglacial-glacial climatic cycle in loess-palaeosol successions of north-western France, Boreas, 28, 551-563.

Basile, I., F. Grousset, M. Revel, J. Petit, P. Biscaye, and N. Barkov (1997), Patagonian origin of glacial dust deposited in East Antarctica (Vostok and Dome C) during glacial stages 2, 4 and 6, Earth Planet. Sci. Lett., 146, $573-589$.

Bettis, E. A., III, D. R. Muhs, H. M. Roberts, and A. G. Wintle (2003), Last glacial loess in the conterminous U.S.A., Quat. Sci. Rev., 22, $1907-$ 1946.

Bidart, S. (1993), Textural characterization and stratigraphic aspects of the late Pleistocene-Holocene eolian sediments in the Sierra de la Ventana area, Buenos Aires Province, Argentina, Quat. Int., 17, 39-47.

Biscaye, P. E., F. Grousset, M. Revel, S. Van der Gaast, G. Zielinski, A. Vaars, and G. Kukla (1997), Asian provenance of glacial dust (stage 2) in the Greenland Ice Sheet Project 2 Ice Core, Summit, Greenland, J. Geophys. Res., 102, 26,765-26,781.

Bonan, G., S. Levis, L. Kergoat, and K. Oleson (2002), Landscapes as patches of plant functional types: An integrating concept for climate and ecosystem models, Global Biogeochem. Cycles, 16(2), 1021, doi:10.1029/2000GB001360.

Bory, A. J.-M., and P. P. Newton (2000), Transport of airborne lithogenic material down through the water column in two contrasting regions of the eastern subtropical North Atlantic Ocean, Global Biogeochem. Cycles, 14, 297-315.

Broecker, W. S., and G. M. Henderson (1998), The sequence of events surrounding Termination II and their implicaions for the cause of glacial-interglacial $\mathrm{CO}_{2}$ changes, Paleoceanography, 13(4), 352-364.

Busacca, A. J., K. T. Nelstead, E. V. McDonald, and M. D. Purser (1992), Correlation of distal tephra layers in loess in the Channeled Scabland and Palouse of Washington State, Quat. Res., 37, 281-303.

Cakmur, R. V., R. L. Miller, J. Perlwitz, D. Koch, I. V. Geogdzhayev, P. Ginoux, I. Tegen, and C. S. Zender (2006), Constraining the magnitude of the global dust cycle by minimizing the difference between a model and observations, J. Geophys. Res., 111, D06207, doi:10.1029/ 2005JD005791.

Chadwick, O. A., L. A. Derry, P. M. Vitousek, B. J. Huebert, and L. O. Hedin (1999), Changing sources of nutrients during four million years of ecosystem development, Nature, 397, 491-496.

Chlachula, J. (2003), The Siberian loess record and its significance for reconstruction of Pleistocene climate change in north-central Asia, Quat. Sci. Rev. 22, 1879-1906.

Collins, W., et al. (2004), Description of the NCAR Community Atmosphere Model (3.0), NCAR Tech. Note TN-464+STR, Natl. Cent. for Atmos. Res., Boulder, Colo. (Available at http://www.ccsm.ucar.edu/ models/atm-cam/docs/description/)

Collins, W., et al. (2006), The community climate system model: CCSM3, J. Clim., in press. (Available at http://www.ccsm.ucar.edu/publications/ jclim04/Papers_JCL04.html)

Delmonte, B., J. R. Petit, K. K. Andersen, I. Basile-Doelsch, V. Maggi, and V. Y. Lipenkov (2004), Dust size evidence for opposite regional atmospheric circulation changes over east Antarctica during the last climatic transition, Clim. Dyn., 23, 427-438, doi:10.1007/s00382-004-0450-9.
DeMott, P., K. Sassen, M. Poellot, D. Baumgardner, D. Rogers, S. Brooks, A. Prenni, and S. Kreidenweis (2003), African dust aerosols as atmospheric ice nuclei, Geophys. Res. Lett., 30(14), 1732, doi:10.1029/ 2003GL017410.

Dentener, F. J., G. R. Carmichael, Y. Zhang, J. Lelieveld, and P. J. Crutzen (1996), Role of mineral aerosol as a reactive surface in the global troposphere, J. Geophys. Res., 101, 22,869-22,889.

Derbyshire, E. (2003), Loess and the Dust indicators and records of Terrestrial and Marine Paleoenvironments (DIRTMAP) database, Quat. Sci. Rev., 22, 1813-1819.

Dickinson, R., et al. (2006), The Community Land Model and its climate statistics as a component of the Community Climate System Model, J. Clim., in press. (Available at http://www.ccsm.ucar.edu/publications/ jclim04/Papers_JCL04.html)

Edwards, M. E., et al. (2000), Pollen-based biomes for Beringia 18,000, 6000 and $0{ }^{14} \mathrm{C}$ years BP, J. Biogeogr., 27(3), 521-554.

Fecan, F., B. Marticorena, and G. Bergametti (1999), Parameterization of the increase of the aeolian erosion threshold wind friction velocity due to soil moisture for arid and semi-arid areas, Ann. Geophys. Atmos. Hydrospheres Space Sci., 17, 149-157.

Fisher, D. A. (1979), Comparison of $10^{5}$ years of oxygen isotope and insoluble impurity profiles from the Devon Island and Camp Century ice cores, Quat. Res., 11, 299-305.

Frechen, M., and A. E. Dodonov (1998), Loess chronology of the Middle and Upper Pleistocene in Tadjikistan, Geol. Rundsch., 87, 2-20.

Frechen, M., E. A. Oches, and K. E. Kohfeld (2003), Loess in Europemass accumulation rates during the Last Glacial Period, Quat. Sci. Rev. $22,1835-1857$

Gallet, S., B. Jahn, B. Van Vliet-Lanoe, A. Dia, and E. A. Rossello (1998), Loess geochemistry and its implications for particle origin and composition of the upper continental crust, Earth Planet. Sci. Lett., 156, 157172

Gillette, D. A. (1979), Environmental factors affecting dust emission by wind erosion, in Saharan Dust, edited by C. Morales, pp. 71-94, John Wiley, Hoboken, N. J.

Gillette, D. A., B. Marticorena, and G. Bergametti (1998), Change in the aerodynamic roughness height by saltating grains: Experimental assessment, test of theory, and operational parameterization, J. Geophys. Res., 103(D6), 6203-6209.

Ginoux, P. (2003), Effects of nonsphericity on mineral dust modeling, J. Geophys. Res., 108(D2), 4052, doi:10.1029/2002JD002516.

Ginoux, P., M. Chin, I. Tegen, J. M. Prospero, B. N. Holben, O. Dubovik, and S.-J. Lin (2001), Sources and distribution of dust aerosols with the GOCART model, J. Geophys. Res., 106(D17), 20,255-20,273.

Grini, A., and C. Zender (2004), Roles of saltation, sandblasting, and wind speed variability on mineral dust aerosol size distribution during the Puerto Rican Dust Experiment (PRIDE), J. Geophys. Res., 109, D07202, doi:10.1029/2003JD004233.

Hand, J., N. Mahowald, Y. Chen, R. Siefert, C. Luo, A. Subramaniam, and I. Fung (2004), Estimates of soluble iron from observations and a global mineral aerosol model: Biogeochemical implications, J. Geophys. Res., 109, D17205, doi:10.1029/2004JD004574.

Harrison, S., K. Kohfeld, C. Roelandt, and T. Claquin (2001), The role of dust in climate changes today, at the last glacial maximum and in the future, Earth Sci. Rev., 54, 43-80.

Haxeltine, A., and I. C. Prentice (1996), BIOME3: An equilibrium terrestrial biosphere model based on ecophysiological constraints, resource availability, and competition among plant functional types, Global Biogeochem. Cycles, 10, 693-709.

J. Houghton, et al. (Eds.) (2001), Climate Change 2001: The Scientific Basis. Contribution of Working Group I to the Third Assessment Report of the Intergovernmental Panel on Climate Change, 881 pp., Cambridge Univ. Press, New York.

Husar, R. B., J. Prospero, and L. Stowe (1997), Characterization of tropospheric aerosols over the oceans with the NOAA advanced very high resolution radiometer optical thickness operational product, J. Geophys. Res., 102, 16,889-16,909.

Iversen, J., and B. White (1982), Saltation threshold on Earth, Mars and Venus, Sedimentology, 29, 111-119.

Joussaume, S. (1990), Three-dimensional simulations of the atmospheric cycle of desert dust particles using a general circulation model, J. Geophys. Res., 95, 1909-1941.

Joussaume, S. (1993), Paleoclimatic tracers: An investigation using an atmospheric general circulation model under Ice Age conditions: 1. Desert dust, J. Geophys. Res., 98, 2767-2805.

Kaplina, T. N., and A. V. Lozhkin (1984), Age and history of accumulation of the "Ice Complex" of the maritime lowlands of Yakutiya, in Late Quaternary Environments of the Soviet Union, edited by A. A. Velichko, H. E. Wright Jr., and C. W. Barnosky, pp. 147-151, Univ. of Minn. Press, Minneapolis. 
Kemp, R. A., P. S. Toms, M. King, and D. M. Kröhling (2004), The pedosedimentary evolution and chronology of Tortugas, a Late Quaternary type-site of the northern Pampa, Argentina, Quat. Int., 114, $101-112$.

Kiehl, J., et al. (2006), The climate sensitivity of the Community Climate System Model: CCSM3, J. Clim., in press.

Kohfeld, K. E., and S. P. Harrison (2001), DIRTMAP: the geological record of dust, Earth Sci. Rev., 54, 81-114.

Kohfeld, K. E., and S. Harrison (2003), Glacial-interglacial changes in dust deposition on the Chinese Loess Plateau, Quat. Sci. Rev., 22, 1859-1878.

Kröhling, D. M. (1999), Upper Quaternary geology of the lower Carcarañá Basin, North Pampa, Argentina, Quat. Int., 57/58, 135-148.

Kröhling, D. M., and M. Iriondo (1999), Upper Quaternary palaeoclimates of the Mar Chiquita area, North Pampa, Argentina, Quat. Int., 57/58, $149-163$.

Little, E. C., O. B. Lian, A. A. Velichko, T. D. Morozova, V. P. Nechaev, K. G. Dlussky, and N. W. Rutter (2002), Quaternary stratigraphy and optical dating of loess from the east European Plain (Russia), Quat. Sci. Rev., 21, 1745-1762.

Liu, T. (1985), Loess in China, 2nd ed., 224 pp., Springer, New York.

Luo, C., N. Mahowald, and J. del Corral (2003), Sensitivity study of meteorological parameters on mineral aerosol mobilization, transport, and distribution, J. Geophys. Res., 108(D15), 4447, doi:10.1029/2003JD003483.

Mahowald, N., and L. Kiehl (2003), Mineral aerosol and cloud interactions, Geophys. Res. Lett., 30(9), 1475, doi:10.1029/2002GL016762.

Mahowald, N., and C. Luo (2003), A less dusty future?, Geophys. Res. Lett., 30(17), 1903, doi:10.1029/2003GL017880.

Mahowald, N., K. Kohfeld, M. Hansson, Y. Balkanski, S. Harrison, C. Prentice, M. Schulz, and H. Rodhe (1999), Dust sources and deposition during the last glacial maximum and current climate: A comparison of model results with paleodata from ice cores and marine sediments, J. Geophys. Res., 104, 15,895-15,916.

Mahowald, N., C. Zender, C. Luo, J. del Corral, D. Savoie, and O. Torres (2002), Understanding the 30-year Barbados desert dust record, J. Geophys. Res., 107(D21), 4561, doi:10.1029/2002JD002097.

Mahowald, N., C. Luo, J. del Corral, and C. Zender (2003), Interannual variability in atmospheric mineral aerosols from a 22 -year model simulation and observational data, J. Geophys. Res., 108(D12), 4352, doi:10.1029/2002JD002821

Mahowald, N., A. Baker, G. Bergametti, N. Brooks, R. Duce, T. Jickells, N. Kubilay, J. Prospero, and I. Tegen (2005), The atmospheric global dust cycle and iron inputs to the ocean, Global Biogeochem. Cycles, 19, GB4025, doi:10.1029/2004GB002402.

Mahowald, N., J.-F. Lamarque, X. Tie, and E. Wolff (2006), Sea salt aerosol response to climate change: Last glacial maximum, preindustrial, and doubled-carbon dioxide climates, J. Geophys. Res., 111, D05303, doi:10.1029/2005JD006459.

Marticorena, B., and G. Bergametti (1995), Modeling the atmospheric dust cycle: 1. Design of a soil-derived dust emission scheme, J. Geophys. Res., 100(D8), 16,415-16,430.

Martin, J. H. (1990), Glacial-interglacial $\mathrm{CO}_{2}$ change: The iron hypothesis, Paleoceanography, 5, 1-13.

McGeehin, J., G. S. Burr, A. J. T. Jull, D. Reines, J. Gosse, P. T. Davis, D. Muhs, and J. R. Southon (2001), Stepped-combustion ${ }^{14} \mathrm{C}$ dating of sediment: A comparison with established techniques, Radiocarbon, 43, $255-261$.

Miller, R., and I. Tegen (1998), Climate response to soil dust aerosols, Am. Meteorol. Soc., 11, 3247-3267.

Miller, R., et al. (2006), Mineral dust aerosols in the NASA Goddard Institute of Space Sciences ModelE atmospheric general circulation model, J. Geophys. Res., 111, D06208, doi:10.1029/2005JD005796.

Muhs, D. R., and E. A. Bettis III (2000), Geochemical variations in Peoria Loess of western Iowa indicate paleowinds of midcontinental North America during last glaciation, Quat. Res., 53, 49-61.

Muhs, D. R., and E. A. Bettis III (2003), Quaternary loess-paleosol sequences as examples of climate-driven sedimentary extremes, Geol. Soc. Am. Spec. Pap., 370, 53-74.

Muhs, D. R., and J. R. Budahn (2006), Geochemical evidence for the origin of late Quaternary loess in central Alaska, Can. J. Earth Sci., in press.

Muhs, D. R., T. A. Ager, E. A. Bettis III, J. McGeehin, J. M. Been, J. E. Begét, M. J. Pavich, T. W. Stafford Jr., and D. Pinney (2003a), Stratigraphy and paleoclimatic significance of late Quaternary loess-paleoso sequences of the last interglacial-glacial cycle in central Alaska, Quat. Sci. Rev., 22, 1947-1986.

Muhs, D. R., T. A. Ager, J. Been, J. P. Bradbury, and W. E. Dean (2003b), A late Quaternary record of eolian silt deposition in a maar lake, St. Michael Island, western Alaska, Quat. Res., 60, 110-122.

Nugteren, G., and J. Vandenberghe (2004), Spatial climatic variability on the Central Loess Plateau (China) as recorded by grain size for the last 250 kyr, Global Planet. Change, 41, 185-206.
Okin, G., N. Mahowald, O. Chadwick, and P. Artaxo (2004), The impact of desert dust on the biogeochemistry of phosphorus in terrestrial ecosystems, Global Biogeochem. Cycles, 18, GB2005, doi:10.1029/ 2003 GB002145.

Otto-Bliesner, B., et al. (2006), Last glacial maximum and holocene climate in CCSM3, J. Clim., in press. (Available at http://www.ccsm.ucar.edu/ publications/jclim04/Papers JCL04.html)

Penner, J. E., et al. (2001), Aerosols, their direct and indirect effects, in Climate Change 2001: The Scientific Basis, edited by J. T. Houghton and et al., 881 pp., Cambridge Univ. Press, New York.

Petit, J. R., L. Mounier, J. Jouzel, Y. S. Korotkevich, V. I. Kotlyakov, and C. Lorius (1990), Palaeoclimatological and chronological implications of the Vostok core dust record, Nature, 343, 56-58.

Péwé, T. L., and A. Journaux (1983), Origin and character of loesslike silt in unglaciated south-central Yakutia, Siberia, U.S.S.R., U.S. Geol. Surv. Prof. Pap., 1262, 46 pp.

Pierce, K. L., M. A. Fosberg, W. E. Scott, G. C. Lewis, and S. M. Colman (1982), Loess deposits of southeastern Idaho: Age and correlation of the upper two loess units, in Cenozoic Geology of Idaho, edited by B. Bonnichsen and R. M. Breckinridge, Idaho Bur. Mines Geol. Bull., 26, 717-725.

Prieto, A. (1996), Late Quaternary vegetational and climatic changes in the Pampa grassland of Argentina, Quat. Res., 45, 73-88.

Prospero, J., and P. Lamb (2003), African droughts and dust transport to the Caribbean: climate change implications, Science, 302, 10241027.

Prospero, J. M., and R. T. Nees (1986), Impact of the North African drought and El Niño on mineral dust in the Barbados trade winds, Nature, 320, $735-738$.

Prospero, J. M., P. Ginoux, O. Torres, S. E. Nicholson, and T. E. Gill (2002), Environmental characterization of global sources of atmospheric soil dust identified with the Nimbus 7 Total Ozone Mapping Spectrometer (TOMS) absorbing aerosol product, Rev. Geophys., 40(1), 1002, doi:10.1029/2000RG000095

Pye, K. (1987), Aeolian Dust and Dust Deposits, 334 pp., Elsevier, New York.

Rasch, P., W. Collins, and B. E. Eaton (2001), Understanding the Indian Ocean Experiment (INDOEX) aerosol distributions with an aerosol assimilation, J. Geophys. Res., 106(D7), 7337-7355.

Rasch, P., D. Coleman, N. Mahowald, D. Williamson, S.-J. Lin, B. Boville, and P. Hess (2006), Characteristics of atmospheric transport using three numerical formulations for atmospheric dynamics in a single GCM framework, J. Clim., in press. (Available at http://www.ccsm.ucar.edu/ publications/jclim04/Papers JCL04.html)

Rea, D. K. (1994), The Paleoclimatic record provided by eolian deposition in the deep sea: The geologic history of wind, Rev. Geophys., 32, 159195.

Reader, M. C., I. Fung, and N. McFarlane (1999), The mineral dust aerosol cycle during the Last Glacial Maximum, J. Geophys. Res., 104, 93819398.

Reddy, M. S., O. Boucher, N. Bellouin, M. Schulz, Y. Balkanski, J. Dufresne, and M. Pham (2005), Estimates of global multicomponent aerosol optical depth and direct radiative perturbation in the Laboratoire de Météorologie Dynamique general circulation model, J. Geophys. Res., 110, D10S16, doi:10.1029/2004JD004757.

Roberts, H. M., D. R. Muhs, A. G. Wintle, G. A. T. Duller, and E. A. Bettis III (2003), Unprecedented last glacial mass accumulation rates determined by luminescence dating of loess from western Nebraska, Quat. Res., 59, 411-419.

Rosenfeld, D., Y. Rudich, and R. Lahav (2001), Desert dust suppressing precipitation: a possible desertification feedback loop, Proc. Natl. Acad. Sci. U. S. A., 98, 5975-5980.

Ruhe, R. V., and C. J. Olson (1978), Loess stratigraphy and paleosols in southwest Indiana, in Guidebook, 25th Field Conference, Midwest Friends of the Pleistocene, 72 pp., Indiana Water Res. Cent. and Dep. of Geol., Bloomington.

Rutledge, E. M., N. Holowaychuk, G. F. Hall, and L. P. Wilding (1975), Loess in Ohio in relation to several possible source areas: I. Physical and chemical properties, Soil Sci. Soc. Am. Proc., 39, 1125-1132.

Rutter, N. W., D. Rokosh, M. E. Evans, E. C. Little, J. Chlachula, and A. Velichko (2003), Correlation and interpretation of paleosols and loess across European Russia and Asia over the last interglacial-glacial cycle, Quat. Res., 60, 101-109.

Schlesinger, W. H., and J. Lichter (2001), Limited carbon storage in soil and litter of experimental forest plots under increased atmospheric $\mathrm{CO}_{2}$, Nature, 411, 466-469.

Sher, A. V., S. A. Kuzmina, T. V. Kuznetsova, and L. D. Sulerzhitsky (2005), New insights into the Weichselian environment and climate of the East Siberian Arctic, derived from fossil insects, plants, and mammals, Quat. Sci. Rev., 24, 533-569. 
Siegel, D. A., and W. G. Deuser (1997), Trajectories of sinking particles in the Sargasso Sea: modeling of statistical funnels above deep-ocean sediment traps, Deep Sea Res., 44, 1519-1541.

Smalley, I. J. (1995), Making the material: the formation of silt-sized primary mineral particles for loess deposits, Quat. Sci. Rev., 14, 645-651.

Smalley, I. J., and D. H. Krinsley (1978), Loess deposits associated with deserts, Catena, 5, 53-66.

Smalley, I. J., and J. A. Leach (1978), The origin and distribution of the loess in the Danube Basin and associated regions of east-central Europe-A review, Sediment. Geol., 21, 1-26.

Smith, J., D. Vance, R. A. Kemp, C. Archer, P. Toms, M. King, and M. Zárate (2003), Isotopic constraints on the source of Argentinian loess-with implications for atmospheric circulation and the provenance of Antarctic dust during recent glacial maxima, Earth Planet. Sci. Lett., 212, 181-196.

Smith, S., T. Huxman, S. Zitzer, T. Charlet, D. Housman, J. Coleman, L. Fenstermaker, J. Seemann, and R. Nowak (2000), Elevated $\mathrm{CO}_{2}$ increases productivity and invasive species success in an arid ecosystem, Nature, 408, 79-82.

Steffensen, J. P. (1997), The size distribution of microparticles from selected segments of the Greenland Ice Core Project ice core representing different climatic periods, J. Geophys. Res., 102, 26,755-26,763.

Sun, J. (2002a), Source regions and formation of loess sediments on the high mountain regions of northwestern China, Quat. Res., 58, 341-351.

Sun, J. (2002b), Provenance of loess material and formation of loess deposits on the Chinese Loess Plateau, Earth Planet. Sci. Lett., 203, 845-859.

Sun, J., K. E. Kohfeld, and S. P. Harrison (2000), Records of Aeolian dust deposition on the Chinese Loess Plateau during the Late Quarternary, technical report, 318 pp., Max-Planck-Inst. für Biogeochem., Jena, Germany.

Swap, R., M. Garstang, S. Greco, R. Talbot, and P. Kallberg (1992), Saharan dust in the Amazon Basin, Tellus, 44B, 133-149.

Tegen, I. (2003), Modeling the mineral dust aerosol cycle in the climate system, Quat. Sci. Rev., 22, $1821-1834$.

Tegen, I., and R. Miller (1998), A general circulation model study on the interannual variability of soil dust aerosol, J. Geophys. Res., 103 25,975-25,995.

Tegen, I., M. Werner, S. P. Harrison, and K. E. Kohfeld (2004), Relative importance of climate and land use in determining present and future global soil dust emission, Geophys. Res. Lett., 31, L05105, doi:10.1029/2003GL019216.

Vandenberghe, J., and G. Nugteren (2001), Rapid climatic changes recorded in loess successions, Global Planet. Change, 28, 1-9.

Velichko, A. A. (1991), Loess-paleosol formation on the Russian Plain, Quat. Int., 7/8, $103-114$.

Velichko, A. A., A. B. Bogucki, T. D. Morozova, V. P. Udartsev, T. A. Khalcheva, and A. I. Tsatskin (1984), Periglacial landscapes of the East European Plain, in Late Quaternary Environments of the Soviet Union, edited by A. A. Velichko, H. E. Wright Jr., and C. W. Barnosky, pp. 95118, Univ. of Minn. Press, Minneapolis.
Virina, E. I., F. Heller, S. S. Faustov, N. S. Bolikhovskaya, R. V. Krasnenkov, T. Gendler, E. A. Hailwood, and J. Hus (2000), Palaeoclimatic record in the loess-palaeosol sequence of the Stretlitsa type section (Don glaciation area, Russia) deduced from rock magnetic and palynological data, J. Quat. Sci., $15,487-499$.

Watson, A. J., D. C. E. Bakker, A. J. Ridgwell, P. W. Boyd, and C. S. Law (2000), Effect of iron supply on Southern Ocean $\mathrm{CO}_{2}$ uptake and implications for glacial atmospheric $\mathrm{CO}_{2}$, Nature, 407, 730-733.

Werner, M., I. Tegen, S. Harrison, K. Kohfeld, I. C. Prentice, Y. Balkanski, H. Rodhe, and C. Roelandt (2002), Seasonal and interannual variability of the mineral dust cycle under present and glacial climate conditions, J. Geophys. Res., 107(D24), 4744, doi:10.1029/2002JD002365.

White, B. R. (1979), Soil transport by winds on Mars, J. Geophys. Res.., 84 , $4643-4651$.

Woodward, S. (2001), Modeling the atmospheric life cycle and radiative impact of mineral dust in the Hadley Centre climate model, J. Geophys. Res., 106, 18,155-18,166.

Wright, J. S. (2001a), "Desert" loess versus "glacial" loess: quartz silt formation, source areas and sediment pathways in the formation of loess deposits, Geomorphology, 36, 231-256.

Wright, J. S. (2001b), Making loess-sized quartz silt: data from laboratory simulations and implications for sediment transport pathways and the formation of 'desert' loess deposits associated with the Sahara, Quat. Int., 76/77, 7-19.

Zárate, M. (2003), Loess of southern South America, Quat. Sci. Rev., 22, $1987-2006$.

Zárate, M., and A. Blasi (1993), Late Pleistocene-Holocene eolian deposits of the southern Buenos Aires Province, Argentina: A preliminary model, Quat. Int., 17, 15-20.

Zender, C., H. Bian, and D. Newman (2003a), Mineral Dust Entrainment and Deposition (DEAD) model: Description and 1990s dust climatology, J. Geophys. Res., 108(D14), 4416, doi:10.1029/2002JD002775.

Zender, C., D. Newman, and O. Torres (2003b), Spatial heterogeneity in Aeolian erodibility: Uniform, topographic, geomorphic, and hydrologic hypotheses, J. Geophys. Res., 108(D17), 4543, doi:10.1029/ 2002JD003039.

Zender, C. S., R. Miller, and I. Tegen (2004), Quantifying mineral dust mass budgets: Terminology, constraints, and current estimates, Eos Trans. $A G U, 85(48), 509-512$.

S. Levis, N. M. Mahowald, and P. J. Rasch, National Center for Atmospheric Research, P.O. Box 3000, Boulder, CO 80307, USA. (mahowald@ucar.edu)

C. Luo and C. S. Zender, Department of Earth System Science, University of California, Irvine, CA 92697, USA.

D. R. Muhs, U.S. Geological Survey, MS 980, Box 25046, Denver, CO 80225, USA.

M. Yoshioka, Institute for Computational Earth Systems Science, University of California, Santa Barbara, CA 93106, USA. 